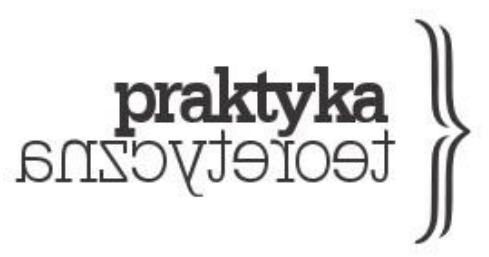

\title{
MODERN MONETARY THEORY A MARKSISTOWSKA KRYTYKA EKONOMII POLITYCZNEJ
}

\section{DAMIAN WINCZEWSKI}

\begin{abstract}
Abstrakt: Niniejszy artykuł jest próbą omówienia problematyki reprezentowanej przez Modern Monetary Theory (Nowoczesną Teorię Monetarna), czyli jedną z popularnych ostatnio teorii zaliczanych do nurtu postkeynesowskiego, w perspektywie marksistowskiej ekonomii politycznej. Przedmiotem analizy będą przede wszystkim założenia MMT dotyczące roli pieniądza we współczesnym świecie - zostaną one zestawione ze współczesnymi badaniami nad marksowską teoria pieniądza towarowego z Kapitału. Skomentowane i ocenione zostaną również pomysły neoczartalistów dotyczące polityki gospodarczej w kapitalizmie oraz jej wpływu na dynamikę całego systemu. Osobną kwestią jest ściśle polityczna problematyka związana z MMT, która również zostanie poddana analizie. Przedstawione zostana punkty wspólne dla niektórych założeń MMT i koncepcji marksistowskich, przy jednoczesnym wykazaniu teoretycznej przewagi propozycji tych drugich. Autor artykułu stara się dowieść, że o ile deskryptywna część omawianej teorii, dotycząca realiów współczesnego kapitalizmu, może być zaakceptowana przez niektórych nieortodoksyjnych ekonomistów marksistowskich, to jej normatywna część powinna spotkać się z krytyką, ze względu na obecne w niej dość powierzchowne powtórzenie niektórych tradycyjnych keynesowskich propozycji dotyczących polityki monetarnej i fiskalnej.
\end{abstract}

Słowa kluczowe: marksizm, neoczartalizm, teoria pieniądza, ekonomia polityczna. 


\section{Wprowadzenie}

Modern Monetary Theory (MMT), czyli Nowoczesna Teoria Monetarna, w niniejszym artykule nazywana przez nas także neoczartalizmem lub postkeynesowską teorią pieniądza1, jest teoria makroekonomiczną analizującą współczesną gospodarkę z punktu widzenia funkcjonowania finansów publicznych w państwach posiadających monopol na kreację niezależnej waluty krajowej w systemie fiat money - czyli w systemie pieniądza fiducjarnego, niemającego oparcia w dobrach materialnych, np. w złocie. Teorię tę często zalicza się do nurtów ekonomii postkeyenesowskiej2. Wśród głównych reprezentantów MMT wymienić można Randalla Wraya, Billa Mitchella oraz Warrena Moslera. Poza analizą współczesnej gospodarki autorzy ci proponują również szereg rozwiązań z zakresu polityki gospodarczej, które w ostatnich latach zdobywają coraz większą popularność, prowokując dyskusję akademicką, a w krajach zachodnich także medialna. Teoria ta jest również bardzo popularna w internetowej blogosferze, do tego stopnia, że pewna część poważnej dyskusji toczy się poza przestrzenią akademicką, właśnie na blogach ekonomistów interesujących się tym zagadnieniem - dlatego też niektóre z nich zostały przez nas wykorzystane jako źródła uzupełniające standardowe publikacje akademickie w postaci książek i artykułów.

Popularność MMT i toczące się wokół niej dyskusje, a także historyczne odniesienia wskazujące na powiązania tej teorii z klasyczną ekonomią (Forstater 2004), w tym z marksizmem, stanowią według nas dobre powody, aby przyjrzeć się jej z perspektywy ekonomii marksistowskiej. Jest to bowiem teoria stawiająca pewne wyzwania przed marksizmem oraz oferująca alternatywna wizję rozwiązań niektórych problemów gospodarczych generowanych przez kapitalizm. Głównym celem niniejszego artykułu jest więc analiza, krytyka i porównanie wybranych koncepcji MMT z odpowiadającymi im koncepcjami ekonomii marksistowskiej. Pośrednimi celami są również wprowadzenie

1 W pewnym sensie nie jest to do końca słuszna nazwa, ponieważ w postkeynesowskiej teorii pieniężnej można rozróżnić teorię cyrkulatywistyczną i (neo)czartalistowską - dzielą one ze sobą większość głównych założeń, a różnica między nimi polega na tym, że teoria cyrkulatywistyczna tłumaczy operacje finansowe między podmiotami prywatnymi, zaś (neo)czartalistowska tłumaczy operacje pomiędzy instytucjami państwowymi a podmiotami prywatnymi (Mitchell 2009b). Dlatego też nie będzie błędem, kiedy przy ogólnej charakterystyce głównych funkcji pieniądza będziemy zamiennie używać terminów MMT, neoczartalizm i postkeynesowska teoria pieniężna.

2 Aczkolwiek niektórzy autorzy nie zgadzają się z tą klasyfikacją, zwłaszcza ci, którzy sami uważają się za reprezentantów postkeynesizmu i są krytyczni wobec MMT (np. Thomas Palley). Również niektórzy zwolennicy MMT, jak np. Bill Mitchell, uważaja, że propagowana przez nich teoria czerpie dużo więcej od Marksa niż od Keynesa. 
do marksistowskiej krytyki postkeynesizmu i prezentacja współczesnego stanu badań w tym zakresie.

Teza artykułu jest taka, że założenia MMT na ogólnym poziomie są słuszne, jeżeli chodzi o deskryptywny opis współczesnej rzeczywistości ekonomicznej, i nie stoją w rażącej sprzeczności z analizami nieortodoksyjnie pojmowanego marksizmu. $\mathrm{Na}$ poziomie normatywnym jednak recepty proponowane przez neoczartalistów w wielu aspektach zawodzą przez swój redukcjonizm i zbyt optymistyczne podejście do kapitalistycznego sposobu produkcji.

Artykuł składa się z pięciu części oraz konkluzji. W części pierwszej zostaną przedstawione geneza i główne założenia MMT. W drugiej części skonfrontujemy je ze współczesnymi badaniami nad Marksowską teorią pieniądza. Trzecia część dotyczyć będzie problemu dynamiki kapitalizmu i punktów stycznych dla marksizmu oraz postkeynesizmu, które stosują się także do koncepcji neoczartalistów. W części czwartej omówiona i poddana krytyce zostanie neoczartalistowska wizja polityki fiskalnej. W ostatniej części podejmiemy zagadnienie implikacji politycznych, które wynikają z przyjęcia założeń MMT. Całość zwieńczy zakończenie zawierające wnioski.

\section{Najważniejsze założenia Modern Monetary Theory}

Żeby szczegółowo opisać wszystkie tezy MMT i różnice w koncepcjach jej najważniejszych propagatorów, potrzebne byłoby odrębne studium. Dlatego omówione zostaną tylko wybrane, najważniejsze założenia MMT, których uznanie wymaga ich bezpośredniego odniesienia do interesujących nas aspektów ekonomii marksistowskiej.

Teoria ta $\mathrm{w}$ istotnej dla nas perspektywie stanowi przede wszystkim negację dogmatów ekonomii neoklasycznej na następujących płaszczyznach: a) pochodzenia pieniądza, b) podaży pieniądza, c) roli deficytu budżetowego, długu publicznego i inflacji, d) zasad funkcjonowania finansów państwowych (Umiński 2014).

W klasycznych i neoklasycznych teoriach pieniądz pełni trzy podstawowe funkcje: po pierwsze, umożliwia przeprowadzanie transakcji, po drugie, stanowi miernik wartości, a po trzecie, pełni funkcje tezauryzacyjną, to znaczy przechowuje daną wartość w czasie (Gruszecki 2015).

Główną cechą (neo)klasycznego podejścia do pieniądza jest podkreślenie jego neutralnego charakteru - zdaniem reprezentantów tej teorii nie wpływa on na inne, realne procesy gospodarcze (Bell 2001; Bludnik 2015, 34). Ponadto mówi się też o - wspomnianej 
już - jego funkcji tezauryzacyjnej: w tym ujęciu pieniądz zawsze przechowuje wartość związana z jakimś towarem lub kruszcem, innymi słowy, jego wartość bierze się z siły nabywczej towaru/kruszcu, na którym jest oparty. Przykładowo, dla Davida Ricarda pieniądz był po prostu złotem lub srebrem - i takim samym towarem jak wszystkie inne $(1817,238)$. Dlatego też przedstawicieli klasycznej teorii pieniądza nazywa się zwolennikami towarowej teorii pieniądza lub - dawniej - „metalistami”. Ekonomiści neoklasyczni, a konkretnie monetaryści, mają bardzo zbliżone przekonania. Twórca teorii monetaryzmu Milton Friedman twierdził, że każda waluta powinna być pośrednio lub bezpośrednio związana z wartością jakiegoś towaru $(1994,22)$.

Zdaniem metalistów historycznie pieniądz wywodzi się z gospodarki barterowej i, jak twierdził Carl Menger, narodził się on spontanicznie oraz oddolnie w celu usprawnienia procesu wymiany towarów. Wówczas środkiem wymiany zostawał inny towar, który reprezentował szczególną wartość dla uczestników transakcji handlowej (2007, 257262). Można powiedzieć, że koncepcja Mengera traktowana jest jako paradygmat we współczesnych analizach ewolucji pieniądza (Kubiczek 2015).

W teorii neoklasycznej kluczową rolę w podaży pieniądza pełnią oszczędności. W tym ujęciu banki najpierw gromadzą oszczędności, żeby następnie udzielać kredytów i pożyczek, które są źródłem inwestycji, co implikuje założenie głoszące, że stopa oszczędności determinuje stope inwestycji. Podejście to wiąże się z przyjmowaną przez ekonomistów klasycznych ilościową teoria pieniężna, który do ekonomii głównego nurtu na powrót wprowadził Friedman (2010). W ramach tej teorii głosi się, że ilość pieniądza znajdująca się w obiegu gospodarczym w liniowy sposób przekłada się na poziom cen. W związku z tym nadmierna ilość inwestycji powoduje wzrost inflacji, zaś odwrotny przypadek skutkuje jej obniżeniem. Neoklasycy zakładają, że podaż pieniądza reguluje się automatycznie, ponieważ kiedy inwestycje są nadmierne, powoduje to wzrost stopy procentowej, co wymusza na inwestorach zmniejszenie nakładów, a to z kolei zwrotnie przyczynia się do spadku ceny dostępnego kredytu.

Ekonomia neoklasyczna bazuje na aksjomacie, zgodnie z którym inwestycje prywatne z założenia są bardziej efektywne niż państwowe. Wobec tego jej przedstawiciele negatywnie zapatrują się na interwencje państwowe, ponieważ te konkurują w walce o środki pieniężne z przedsiębiorstwami prywatnymi. Efektem tej konkurencji jest wypieranie inwestycji prywatnych przez inwestycje państwowe. Głównym źródłem inwestycji 
państwowych jest zwiększający się deficyt budżetowy. Ponieważ zdaniem neoklasyków wolny rynek reguluje się sam i zapewnia optymalną alokację zasobów, to interwencja państwa nie prowadzi do zmian w zagregowanym wolumenie produkcji gospodarki narodowej, lecz wskutek zwiększenia ilości pieniądza w obiegu prowadzi jedynie do wzrostu cen3.

Szkoła monetarystyczna dopuszcza jedynie ograniczoną interwencję, którą może w uzasadnionych warunkach przeprowadzić niezależny od rządu bank centralny. Wpływa on na poziom podaży pieniądza w gospodarce, regulując stopę procentową oraz stopę rezerwy obowiązkowej w bankach. Kontroluje również operacje otwartego rynku, które polegają na zakupie bądź sprzedaży bonów oraz papierów wartościowych, starając się w ten sposób zabezpieczyć rynek pieniężny przed nieoczekiwaną utratą płynności. Tym samym uznaje, że pieniądz ma charakter egzogeniczny.

Genezą wielu założeń MMT jest trwający od wielu lat spór o pochodzenie i rolę pieniądza, toczony między zwolennikami i przeciwnikami zarysowanego przez nas powyżej stanowiska. W historii myśli ekonomicznej nazywano go często sporem pomiędzy metalizmem a czartalizmem, określanym czasem również jako stanowisko nominalistyczne (Wray 2015, 162). Aczkolwiek współcześnie mówi się raczej o sporze pomiędzy zwolennikami pieniądza egzogenicznego i endogenicznego.

Za ojca czartalizmu powszechnie uważa się niemieckiego ekonomistę Georga Friedricha Knappa. W swojej wydanej w 1895 roku w Niemczech, a w latach dwudziestych przetłumaczonej na język angielski książce State Theory of Money twierdził, że pieniądz nie jest towarem, ale tworem prawnym stworzonym i wprowadzonym do obiegu przez państwo.

Nie miało dla niego znaczenia, czy pieniądz istnieje w formie złota czy papieru, ponieważ utrzymywał, że należy traktować go jako kupon bądź żeton (wł. charta), który za sprawą umowy społecznej umożliwia ludziom wymianę handlową (Knapp 1924, 32). Jego poglądy miały wpływ na Johna Maynarda Keynesa, który również krytykował klasyczne podejście do pieniądza (1930). Podobnie żyjący w tych samych czasach ekonomista brytyjski Alfred Mitchell-Innes głosił pogląd, że pieniądz jest relacją społeczną pomiędzy dłużnikiem i wierzycielem, niezależnie od tego, czy wierzycielem jest państwo czy podmioty prywatne (1914). Współcześnie neoczartaliści tacy jak Mosler uważają, że pieniądz niezależnie od formy, jaką przybiera - papierowej, kruszcowej bądź jakiejkolwiek innej - nie różni się

3 W ostatnim czasie teoria ta jest krytykowana nie tylko przez postkeynesistów, ale również przez ekonomistów z banków centralnych (zob. np. Disyatat 2010; Aldasoro i Unger 2017). 
niczym od elektronicznego zapisu na koncie. Zapis ten jest wart tylko tyle, ile jest wart w momencie zawarcia konkretnej transakcji, to znaczy jego wartość równa jest zakupionym dobrom i usługom w danej chwili (Mosler 2014, 57).

Istotą czartalizmu jest teza, że to państwo stwarza publiczne zapotrzebowanie na walutę poprzez ogłaszanie podatków, które muszą być płacone przez obywateli w walucie krajowej. Zwolennicy tej teorii uważaja, że opisuje ona funkcjonowanie wszystkich systemów monetarnych. Ważnym czynnikiem tych systemów jest swoboda fiskalna państwa - będzie ona duża, jeżeli państwo jest suwerennym emitentem własnej waluty o płynnym kursie (niezwiązanym z kursem innej waluty - jest to kluczowe dla jej niezależności), zaś mniejsza, jeżeli kurs waluty będzie sztywny lub powiązany ze standardem złota.

Współcześnie zwolennicy MMT w pełni przyjmują te założenia, traktując przejście z systemu pieniądza opartego na kruszcu do systemu fiat money - czyli pieniądza niemającego pokrycia w żadnym towarze, kreowanego przez banki centralne ex nibilo - jako potwierdzenie powyższej teorii. Wciąż trwa spór między metalistami a czartalistami o to, czy pieniądz rzeczywiście narodził się spontanicznie podczas wymiany barterowej czy na skutek działań państwa. Prowadzone badania sięgają czasów starożytności i pierwszych instytucji państwowych w tej epoce (Semenova 2011, Bransbourg 2011).

Stanowisko zajęte w dyskusji o pochodzeniu i funkcjach pieniądza niesie ze sobą poważne implikacje makroekonomiczne. Współcześni kontynuatorzy czartalistów przyjmuja, że podatki nie finansują wydatków państwa. Wręcz przeciwnie, to państwo nakłada podatki w tym celu, aby stworzyć zapotrzebowanie na kreowana przez siebie walutę i używa polityki fiskalnej do regulacji zachowań podmiotów gospodarczych (Mosler 2014, 31). Innymi słowy, następuje tutaj odwrócenie słynnego bon motu Margaret Thatcher, że rząd nie ma żadnych własnych pieniędzy. W pewnym sensie w państwie będącym suwerennym emitentem własnej waluty rząd „ma wszystkie pieniądze” i tworzy obciążenia fiskalne, aby podaży waluty odpowiadał popyt na nią.

W związku z tym np. głośny współcześnie problem kryzysu systemu emerytalnego dla neoczartalistów nie sprowadza się do kwestii gromadzenia pieniędzy na wypłatę emerytur. Według nich państwowy system emerytalny czy ubezpieczeniowy nie może zbankrutować, bo zgromadzone w nim środki nie są niczym więcej niż tylko zapisem na koncie (Mosler 2014, 73). Prawdziwym problemem jest więc zapewnienie takich warunków gospodarczych, w których możliwe będzie wytworzenie odpowiedniej ilości dóbr i usług koniecznych 
do zaspokojenia potrzeb emerytów (Winczewski 2016). Dlatego można powiedzieć, że choć MMT jest w dużej mierze teorią funkcjonowania finansów, to realnym skutkiem przyjęcia jej założeń jest przynajmniej częściowe przesunięcie uwagi polityki gospodarczej z fetyszyzowanego przez neoliberałów sektora finansowego na sferę realnej pracy i produkcji.

Przyjęcie powyższych tez o pochodzeniu i roli pieniądza implikuje odmienne względem teorii neoklasycznej stanowisko dotyczące podaży pieniądza i funkcjonowania finansów państwowych. Według zwolenników MMT koncepcja egzogeniczności pieniądza i możliwości sprawowania nad nim pełnej kontroli przez bank centralny jest mocno wattpliwa. Zdaniem Wraya uznanie silnej („teoretycznej”) egzogeniczności pieniądza wymagałoby ignorowania zmiennych endogenicznych, takich jak: wydatki, stopa procentowa, bezrobocie, inflacja oraz popyt sektora prywatnego na kredyt (1992). Realistycznie rzecz ujmując, bank centralny musi mieć te zmienne na uwadze, co potwierdza raczej założenie o endogeniczności pieniądza.

Ponadto reprezentanci postkeynesowskiej teorii pieniądza przyjmują, że kreacja pieniądza zajmują się też banki komercyjne, a mówiąc precyzyjniej, stwierdzają, że pieniądz w gospodarce może być tworzony i niszczony. Schemat ten opisywaliśmy w innym artykule:

Z każdym udzielonym kredytem bank tworzy nowy depozyt, którego skutkiem jest powstanie nowej siły nabywczej. Innymi słowy, bank nie wykorzystuje istniejących depozytów („nikomu nie zabiera”), aby udzielić kredytu. Nowe depozyty tworzą nowe aktywa (należności kredytobiorcy względem banku) i pasywa (kwota do wykorzystania przez kredytobiorcę). Analogicznie spłata kredytu powoduje destrukcję pieniądza. Podobnie kreacją nowego pieniądza jest skup/wyprzedaż przez bank centralny instrumentów finansowych reprezentujących sektor publiczny (np. obligacji) (Winczewski 2015).

Powyższy mechanizm kreacji i destrukcji pieniądza potwierdza publikacja Banku Anglii (2014) oraz kilka innych, w tym również publikacja Narodowego Banku Polskiego (Kapuściński et al. 2016). W związku z tym możliwości banku centralnego co do kontrolowania podaży pieniądza są bardzo ograniczone i sprowadzają się w zasadzie do kontrolowania stopy procentowej. Zwolennicy MMT są również dość sceptyczni, jeżeli chodzi o skuteczność stosowania instrumentu polityki pieniężnej, jakim jest wyznaczanie stopy rezerwy obowiązkowej. Twierdzi się bowiem, że za kreację pieniądza nie odpowiadają 
oszczędności, lecz konieczność wzmożonych wydatków. Implikuje to założenie, że poziom rezerw trzymanych przez banki komercyjne w banku centralnym w dużym stopniu zależy od zmiennych endogenicznych, tj. od aktualnej sytuacji na rynku, i w mniejszym stopniu wpływają nań odgórne dyrektywy władz banku centralnego co do poziomu rezerwy minimalnej.

Przyjmowana przez postkeynesistów endogeniczność pieniądza prowadzi również do odrzucenia ilościowej teorii pieniądza4 i wynikających z niej poglądów dotyczących inflacji. Ekonomiści neoklasyczni zakładaja, że wolnorynkowa gospodarka oparta jest na samoregulującym się mechanizmie prowadzącym do maksymalnego wykorzystania środków produkcji. Wskutek tego włączenie się państwa do gry rynkowej powoduje presję inflacyjną i w rezultacie wzrost kosztów produkcji. Postkeynesiści twierdzą jednak, że w gospodarce rynkowej nie mamy do czynienia z pełnym wykorzystaniem środków produkcji, co uchyla furtkę dla interwencji państwowej. Wedle przyjmowanych przez nich założeń dodatkowe wydatki finansowane z deficytu budżetowego nie przekładają się w sposób liniowy na wzrost inflacji, dopóki nie zostanie osiagnięty stan pełnego wykorzystania środków produkcji. Do tego momentu w przypadku wystąpienia nadwyżkowego popytu przedsiębiorstwa prywatne nie zwiększałyby cen, tylko ilość produkowanych towarów. Dopuszcza się jednak możliwość wzrostu stopy inflacji przy niepełnym wykorzystaniu środków produkcji. Wyniknać może to ze strony podażowej na przykład wtedy, gdy przy zwiększonych inwestycjach brakuje wykwalifikowanych pracowników mogących obsłużyć zamówienia strony inwestującej. Z zasady jednak skutki inflacyjne takiej sytuacji powinny być tymczasowe i ograniczone do branży, w której brakuje rąk do pracy. Wzrost poziomu inflacji może wystapić również wtedy, kiedy popyt będzie rósł szybciej niż możliwości produkcyjne gospodarki (Umiński 2014).

Generalnie rzecz biorąc, główne różnice w poglądach dotyczących pieniądza między szkołą neoklasyczną a MMT można ująć w poniższej tabeli:

4 Krytykuje ona większość jej założeń: a) założenie kontroli podaży pieniądza przez bank centralny, b) tezę, zgodnie z która szybkość obiegu pieniądza jest taka sama na różnych etapach cyklu gospodarczego i c) wykorzystanie pełni mocy produkcyjnych gospodarki. 


\begin{tabular}{|l|l|l|}
\hline Pieniądz & Według neoklasyków & Według MMT \\
\hline Pochodzenie & Wymiana barterowa & Polityka fiskalna państwa \\
\hline Charakter & Egzogeniczny & Endogeniczny \\
\hline Rola & Neutralna & $\begin{array}{l}\text { Powiązana innymi } \\
\text { elementami gospodarki }\end{array}$ \\
\hline Kreacja & Bank Centralny & $\begin{array}{l}\text { Bank Centralny i banki } \\
\text { komercyjne }\end{array}$ \\
\hline Podaż & Oszczędności wanku & Kredyt kreowany ex nibilo \\
\hline
\end{tabular}

Tabela 1. Zestawienie głównych ró:̇nic w ujęciach funkcjonowania pieniadza w gospodarce kapitalistycznej między sqkota neoklasyczna a Modern Monetary Theory

\section{Źródto: opracowanie własne}

Jak widać, podejścia prezentowane w ramach obu szkół są przeciwstawne i wykluczające się nawzajem, co prowadzi do istotnych implikacji praktycznych. Odrzucenie neoklasycznych dogmatów wiedzie do afirmacji aktywnej polityki fiskalnej państwa kosztem polityki pieniężnej, która przez neoklasyków stawiana jest na pierwszym miejscu, jeżeli chodzi o ogół polityki gospodarczej państwa. Podstawowym źródłem pomysłów zwolenników MMT na politykę finansowa prowadzoną przez państwo jest słynny artykuł Abby Lernera o finansach funkcjonalnych.

Tezy Lernera sprowadzają się do następujących twierdzeń:

1) Głównym zadaniem rządu jest kontrola siły nabywczej obywateli. Przy zbyt niskich wydatkach sektora prywatnego zadaniem państwa jest interwencja i obniżka podatków lub zwiększenie wydatków. Kiedy wydatki prywatne są zbyt wysokie, wtedy rząd powinien ciąć swoje wydatki lub podwyższyć podatki.

2) Państwo powinno dbać o optymalizację wydatków inwestycyjnych w gospodarce. W tym celu może regulować stopy procentowe. Może się zadłużyć w celu ich podwyższenia lub spłacić długi w celu ich obniżenia.

3) Jeżeli powyższe metody będą zawodzić, rząd w celu naprawy sytuacje może emitować swoją walutę w dowolnej ilości (Lerner 1943). 
Powyższe tezy zostały wpisane w zasady polityki gospodarczej postulowane przez MMT. W zasadzie postulaty dotyczące polityki fiskalnej sformułowane w ramach tej teorii sprowadzają się do oceny finansowania wydatków rządowych za pomocą deficytu budżetowego. Za Billem Mitchellem można stwierdzić, że w wyznaczaniu dochodu narodowego kluczowa jest prosta zasada: deficyt sektora publicznego równy jest nadwyżce sektora prywatnego. W związku z tym, że efektywny popyt równy jest rzeczywistemu dochodowi narodowemu, w rezultacie ex post tożsamość rachunku bilansów sektorowych przyjmuje następująca postać:

$$
(\mathbf{G}-\mathbf{T})=(\mathrm{S}-\mathbf{I})-\mathbf{N X}
$$

gdzie G - wydatki rządowe, T - podatki, S - oszczędności sektora prywatnego, I - inwestycje, a NX - eksport netto (Mitchell 2009a).

Według Mitchella, ogólnie rzecz ujmując, oszczędności sektora prywatnego netto nie moga istnieć bez skumulowanych wydatków rządowych finansowanych deficytem budżetowym. W modelu gospodarki zamkniętej, gdzie nie występuje eksport $(\mathrm{NX}=0)$, deficyt budżetowy przekłada się liniowo na oszczędności prywatne (dolar za dolara czy złotówka za złotówkę). W gospodarce otwartej zaś suma oszczędności prywatnych składa się z inwestycji prywatnych, deficytu budżetowego i eksportu netto. Jednak generalnie rzecz biorąc, zdaniem Mitchella jedyna jednostka, która może zapewnić sektorowi prywatnemu aktywa finansowe (oszczędności) netto i wyeliminować bezrobocie, jest sektor publiczny.

Z tej perspektywy zwiększanie wydatków rządowych finansowanych z deficytu budżetowego pełni więc pozytywną rolę, stymulując rozwój całego sektora prywatnego. Prowadzi to do konkluzji, że inwestycje dokonane przez państwo przekładać się będą na wyższe oszczędności sektora prywatnego. Nadmierny deficyt zaś zgodnie z tezami Lernera może być korygowany przez politykę podatkowa (Mosler 2014, 91).

Podsumowując ogólny zarys MMT, można stwierdzić, że teoria ta zbudowana jest w dużej mierze na dość starych konceptach, wywodzących się z klasycznego keynesizmu i czartalizmu. Przemiany gospodarcze, z którymi mieliśmy do czynienia w ostatnich dekadach, na czele $z$ porzuceniem standardu kruszcowego, a także kolejnymi kryzysami finansowymi spowodowanymi neoliberalna polityką, sprzyjały odświeżeniu zrekonstruowanych przez nas powyżej poglądów. MMT w przestrzeni publicznej bywa często krytykowana za ogólnikowość i duży poziom uproszczenia. Rozmaite kontrowersje wzbudzają również 
szczegóły proponowanych w ramach MMT rozwiązań. Jest to jednak teoria, która wciąż zyskuje popularność w świecie ekonomii heterodoksyjnej. Z tego względu konieczne wydaje się przeanalizowanie jej założeń i odniesienie się do nich z perspektywy marksistowskiej.

\section{Konsekwencje dla marksistowskiej teorii wartości}

Analizowanie głównych założeń MMT z perspektywy marksistowskiej wpisuje się w szerszy dialog pomiędzy ekonomią marksistowską a postkeynesizmem, który toczy się już od wielu lat. Wielu postkeynesistów, czy w ogóle ekonomistów heterodoksyjnych, niezależnie od tego, czy zgadzają się z tezami MMT na temat funkcjonowania pieniądza we współczesnym kapitalizmie, z różnych powodów popiera aktywną rolę państwa w gospodarce, finansowanie rozwoju deficytem budżetowym, uznaje politykę fiskalną za bardziej istotną od polityki pieniężnej etc.

Również wiele ogólnych założeń MMT dotyczących pieniądza, takich jak uznanie jego endogenicznego charakteru w kapitalistycznej gospodarce czy pogląd, że pieniądz jest kreowany w momencie zaciagnnięcia długu, jest znanych i raczej powszechnie akceptowalnych w doktrynie postkeynesowskiej (Lavoie 1984). Rzecz jasna podobnie jak w innych nurtach ekonomii heterodoksyjnej wiąże się to z krytyką neoklasycznych założeń o neutralności pieniądza (Fontana 2000, 2003).

Nie będziemy w tym miejscu analizować złożonych relacji pomiędzy poglądami zwolenników MMT a poglądami innych postkeynesistów, ani też rekonstruować zaciętych dyskusji wokół poszczególnych założeń tej teorii, które miały miejsce w ostatnich latach. Chcemy skupić się wyłącznie na relacji pomiędzy MMT a marksizmem, pamiętając jednak, że krytyka tego drugiego z pozycji MMT jest w dużej mierze częścią ogólnej postkeynesowskiej recepcji marksistowskiej ekonomii politycznej.

Aby ustalić stosunek między MMT a marksistowską teorią wartości, trzeba odpowiedzieć sobie na pytanie, jaki jest rzeczywisty charakter teorii pieniądza wyłożonej przez Marksa w Kapitale. Standardowa interpretacja głosi, że w dziele tym mamy do czynienia z towarową teoria pieniądza. Zdaniem niektórych ekonomistów założenie o towarowej naturze pieniądza jest teoretyczną koniecznościa, wynikającą z logicznej struktury Kapitału. Z faktu, że żyjemy współcześnie w epoce fiat money, wyciagnięto wniosek, iż pieniądz nie posiada już towarowego charakteru, zatem realia współczesnej gospodarki stoja w sprzeczności z teorią Marksa (Lavoie 1986). 
Rzeczywiście towarowa teoria pieniądza wyłożona przez Marksa w I tomie Kapitału wydaje się potwierdzać te przypuszczenia. Myśliciel z Trewiru przyjął tam w gruncie rzeczy podobną do teorii Mengera koncepcję genezy pieniądza, wedle której pieniądz wyłonił się spontanicznie w toku społecznego rozwoju produkcji i handlu, jako uniwersalne medium wymiany: „Społeczne działanie wszystkich innych towarów wydziela więc określony towar, za pomocą którego wyrażają one wszechstronnie swoją wartość" (Marks 1951, 92). Z historycznego punktu widzenia pieniądz miał być koniecznym wytworem rozwoju formy towarowej: „w miarę jak produkty pracy przeistaczają się w towary, towar przeistacza się w pieniądz" (1951, 93). Samych źródeł formy pieniężnej Marks upatrywał w aktywności plemion koczowniczych, które wchodząc w interakcję z innymi wspólnotami, potrzebowały łatwo zbywalnych, ruchomych ekwiwalentów pieniężnych, do których można było zaliczyć m.in. niewolników (1951, 94-95).

Trzeba jednocześnie oddać niemieckiemu filozofowi, że w przeciwieństwie do ekonomistów głównego nurtu daleki był od analizowania gospodarki kapitalistycznej w kategoriach prostej wymiany towarowej. Choć zdawał się przyjmować hipotezę gospodarki barterowej jako źródła pochodzenia pieniądza, to odrzucał wszelkie podobieństwo między nią, a realiami współczesnego mu rynku kapitalistycznego. Nie przyjmował więc założenia o wzajemnej wymienialności dowolnych towarów, uważał, że w gospodarce kapitalistycznej ich społeczna forma musi być uznana i zapośredniczona przez medium jednego towaru pieniądza. Dlatego też specyficzną cechą kapitalizmu jest nie wymiana towarowa, lecz obecność pieniądza i cyrkulacji pieniężnej5 (Milios, Dimoulis i Economakis 2002, 28).

Pieniądz w rozumieniu Marksa jest więc towarem ogólnym, co bynajmniej nie znaczy, że posiada jakass immanentną wartość. Cechuje go bowiem posiadanie pewnej szczególnej formy wartości. Oznacza to, że jak każdy inny towar można wycenić go tylko w innych towarach, a do wyceny tej dochodzi z chwilą wejścia pieniądza do cyrkulacji. Świeżo wykopane złoto lub srebro posiada już rynkową wartość, odzwierciedlająca społecznie niezbędną pracę będąca źródłem wartości towarów, które stanowią ekwiwalent danej ilości kruszcu. Innymi słowy, zawiera czystą wartość wymienną (Marks 1986, 129). Stąd też

5 Założenie to rozbija rzecz jasna słynną formułe T-P-T (towar-pieniądz-towar) na formuły T-P i P-T, co opisywał Marks na kolejnych stronicach Kapitału. Ujawnia to, że na każdym etapie kapitalistycznej wymiany handlowej kluczową rolę odgrywa właśnie pieniądz, który w ekonomii klasycznej przedstawiany był jako neutralna „zasłona” wymiany towarów, w której transakcje przebiegać miałyby w zasadzie podobnie jak w barterze. 
zdaniem Marksa bierze się fetyszyzm pieniężny, będący szczególną formą fetyszyzmu towarowego: przekonanie o magicznej wartości kruszcu, która pozornie jest niezależna od pracy ludzkiej i stosunków społecznych (1951, 96-99).

Kiedy nasza analizę ograniczymy do pierwszych ksiag Kapitału, to z perspektywy czartalistowskiej może się wydawać, że trewirski filozof zatrzymał się w połowie drogi. Rozpoznawał on bowiem znaczący wpływ państwa na kreację i obieg pieniądza. Opisał historyczną ewolucję, podczas której bite monety zawierały stopniowo coraz mniejszą ilość kruszcu, aż do momentu, gdy zaczęły być wypierane przez pieniądz papierowy, który sam jako materiał będąc czymś niemal bezwartościowym, formalnie stał się znakiem banknot papierowy symbolizować miał daną ilość kruszcu (Marks 1951, 132-133). Jednocześnie, analizując pieniądz papierowy, Marks faktycznie zbliżył się do „praw” ilościowej teorii pieniądza (którą w innych miejscach krytykował ${ }^{6}$ ) - w jego wizji papierowy pieniądz nie był czartalistowskim żetonem, ponieważ faktycznie jego ilość powinna odpowiadać wyobrażonej ilości złota, które powinno krążyć w obiegu, jeżeli wszystkie pieniądze papierowe wymieniłoby się na oznaczoną przez nie ilość złota (1951, 134-135). Zatem jeżeli ilość pieniądza papierowego w obiegu byłaby dwukrotnie wyższa niż potencjalne rezerwy złota, wówczas ceny powinny być dwukrotnie wyższe. W związku z tym pieniądz papierowy ma tylko „byt na pozór oderwany od swej substancji kruszcowej” $(1951,136)$.

Niemniej jednak w świetle współczesnej wiedzy trudno byłoby uznać teorię Marksa za czystą teorię pieniądza towarowego. Po pierwsze z tych powodów, które w swojej książce przedstawił Marek Łagosz. Przesłanką wartości wymiennej pieniądza w koncepcji niemieckiego filozofa, odróżniająca pieniądz od innych towarów, nie jest zapotrzebowanie na konkretną wartość użytkową. Pieniądz w każdej postaci posiada wartość użytkową tylko umownie, nie może być skonsumowany indywidualnie, lecz o ile nie został odłożony jako środek oszczędności, musi zawsze cyrkulować w gospodarce. Wypowiedzi Marksa dotyczące pieniądza kredytowego przedstawione w III tomie Kapitatu i wcześniej, w Zarysie krytyki ekonomii politycznej, świadczą - zdaniem Lagosza - o tym, że de facto w ujęciu Marksowskim pieniądz nie jest nośnikiem wartości, lecz reprezentuje siłę nabywczą (Lagosz 2012, 64-65).

Uznanie pieniądza nie za towar, ale przede wszystkim za znak/symbol określonej siły nabywczej, nieco osłabia krytykę Marksowskiej teorii pieniądza z perspektywy

6 Marks był krytyczny wobec ilościowej teorii pieniądza, ponieważ ta traktowała pieniądz jedynie jako środek cyrkulacji i negowała jego związki z wartością. Dla niemieckiego filozofa pieniądz był przede wszystkim nośnikiem wartości, co poprzedzało jego znaczenie jako środka cyrkulacji (Campbell 2005). 
rzeczywistości fiat money, ponieważ wydaje się to oddalać konieczny związek między prawomocnościa tej teorii a np. obowiązywaniem standardu złota. Nie zmienia to faktu, że teoria ta pozostaje w ścisłym związku z teorią wartości. Jeżeli nawet po likwidacji standardu kruszcowego przestalibyśmy uznawać kruszce za główny punkt odniesienia dla pieniądza papierowego, to według Marksowskich założeń i tak powinniśmy uważać, że łączna siła nabywcza pieniądza znajdującego się w obiegu powinna odpowiadać wolumenowi społecznie niezbędnego czasu pracy zawartego w towarach znajdujących się na rynku.

Zrozumienie i ustalenie relacji, w jakiej Marksowska teoria pieniądza znajduje się względem nowoczesnej teorii pieniądza, wymaga przeglądu kilku kluczowych stanowisk reprezentowanych przez czołowych współczesnych ekonomistów marksistowskich.

Pierwszym z nich jest stanowisko zajmowane przez Augusto Grazianiego. Jego główna teza głosi, że pieniądz w Marksowskiej teorii nie ma w pełni charakteru towarowego, jak również nie można uznać go za czysty pieniądz kredytowy. Generalnie jednak podejście tego ekonomisty w pewnym ograniczonym zakresie afirmuje towarowy charakter pieniądza. Punktem wyjścia analiz Grazianiego jest uznanie podwójnej funkcji pieniądza - jest on nie tylko ogólnym ekwiwalentem, ale także sam w sobie jest relacją społeczną, ponieważ łączy kapitał i pracę. Towarowość pieniądza wydaje się włoskiemu ekonomiście problematyczna ze względów ontologicznych. W uproszczonym modelu, kiedy ograniczymy funkcję pieniądza do fazy produkcji, wówczas wydaje się jasne, że pieniądz nie może mieć charakteru towarowego. Kapitalista bowiem używa pieniędzy do nabycia siły roboczej, dzięki której będzie mógł produkować towary. Z tego punktu widzenia nielogiczne wydaje się to, żeby kapitalista używał towaru do kupna siły roboczej. Ponadto pieniądz jako towar musiałby być wytworem wcześniejszego procesu produkcyjnego. Jeżeli uznalibyśmy pieniądz za towar, to zakładałoby to istnienie przed fazą produkcji jakiegoś charakterystycznego towaru spełniającego funkcję pieniądza, którego pochodzenia nie bylibyśmy w stanie wytłumaczyć. Zdaniem Grazianiego powinniśmy zrezygnować z przyznawania pieniądzom jakiejś stałej, uniwersalnej natury. Zamiast tego trzeba rozważyć hipotezę głosząca, że pieniądz zmienia swoją naturę w zależności od tego, w której fazie cyrkulacji się znajduje - w fazie początkowej wymiany między pracą i kapitałem czy na etapie cyrkulacji towarowej (Graziani 1997). 
Jak autor argumentuje dalej, nie ma powodu, by na etapie cyrkulacji towarowej negować, że pieniądz jest towarem, uniwersalnym ekwiwalentem, który umożliwia pozyskanie innych towarów. Kiedy spojrzymy na gospodarkę naturalna, gdzie nie ma podziału pomiędzy praca a środkami produkcji, z logicznego punktu widzenia klasyczna hipoteza natury pieniądza - w której jego funkcję pełni oddolnie wybrany przez społeczność towar umożliwiający handel nadwyżkami produkcyjnymi - nie budzi żadnych zastrzeżeń. Jednak gdy wrócimy do kwestii wymiany pracy na kapitał na etapie początkowym cyrkulacji w gospodarce kapitalistycznej, okaże się, że pieniądz musi mieć siłę nabywczą, nie będąc jednocześnie towarem. Zatem w fazie początkowej cyrkulacji pieniądz z konieczności ma charakter kredytowy.

Zdaniem Grazianiego założenie to nie jest sprzeczne $z$ teorią Marksa. Argumentował on, że niemiecki filozof nie tworzył swoich analiz pieniądza towarowego w oparciu o model czystej gospodarki kapitalistycznej - zakładał w poszczególnych miejscach wymianę międzynarodową oraz interwencję państwa; w związku z tym jego uwaga poświęcona pieniądzowi kruszcowemu wynikała z faktu, iż ten stanowił w owych czasach najpewniejszą walutę rozliczeniową w transakcjach międzynarodowych i międzypaństwowych. Marksowskie analizy płacy roboczej mają dowodzić, że założenie kredytowego charakteru pieniądza w początkowej fazie cyrkulacji nie jest sprzeczne z treścią Kapitału. Marks podkreślał bowiem, że wszelkie rozliczenia między kapitalistą i robotnikiem z zasady zachodzą ex post. Możemy więc powiedzieć, że faktycznie w początkowej fazie produkcji kapitalista pozyskuje siłę roboczą na kredyt, zobowiązując się wobec robotnika, że dostarczy mu w czasie określonym umową środków na pozyskanie niezbędnych dla niego dóbr.

Pozostaje kluczowe pytanie - co z wartością pieniądza? Jak przekonywał Graziani, w gospodarce kapitalistycznej pieniądz nie służy do zapewnienia obrotu na rynku już wyprodukowanych towarów, lecz jest środkiem inicjującym produkcję towarową. Nie jest uznawany za trwale pozyskany środek (stanowiący jakąś rezerwę kapitałowa), ale za krótkoterminową pożyczkę zapewniającą płynność podczas cyklu produkcyjnego. Po jego zakończeniu pieniądze wracają do pożyczkodawcy lub służą do rozpoczęcia kolejnego cyklu. W związku z tym każdy, kto używa pieniądza jako kapitału, nie zestawia czasu pracy koniecznego do produkcji towarów z czasem niezbędnym do produkcji pieniądza, ale wykorzystany czas pracy z odsetkami płaconymi instytucji finansowej. Czym 
innym jest zatem wartość pieniądza w relacji między finansistą i przedsiębiorcą, a czym innym w relacji między przedsiębiorcą i rynkiem. Zdaniem Grazianiego przyczyna nieporozumień co do związku wartości pieniądza ze społecznie niezbędnym czasem pracy leży w nieprawidłowym odczytaniu metodologicznych założeń Kapitału - Marks, twierdząc, że ceny towarów są skorelowane ze zużytym na nie czasem pracy, mówił o tym w sensie całościowym, odnosząc się do społeczeństwa jako ogółu złożonego z dwóch głównych klas. Nie znaczy to jednak, że wartość transakcji pieniężnych dokonywanych przez kapitalistę indywidualnego wykazuje silną korelację ze społecznie niezbędnym czasem pracy (Graziani 1997).

Inaczej mówiąc, włoskiemu ekonomiście chodziło o to, że w gospodarce kapitalistycznej ujmowanej jako całość wartość pieniędzy znajdujących się w obiegu powinna mniej lub bardziej odpowiadać wartości znajdujących się w obiegu towarów i zawartej w nich wartości dodatkowej. Jednocześnie na poziomie indywidualnym inwestycje poszczególnych przedsiębiorców moga być z powodzeniem finansowane pieniądzem kreowanym i niszczonym przez instytucje finansowe, którego wartość nie ma bezpośrednio nic wspólnego z czasem pracy.

Innym ważnym ekonomistą przeciwstawiającym się odczytaniu Marksowskiej koncepcji pieniądza jako pieniądza towarowego jest Fred Moseley. Podobnie jak dla Grazianiego, również dla Moseleya oczywiste jest to, że w teorii Marksowskiej od czasu Prayczynku do krytyki ekonomii politycznej pieniądz jako środek cyrkulacji w gospodarce kapitalistycznej nie musi być towarem (Marks 1953, 93-122). Zdaniem amerykańskiego ekonomisty kluczowa jest odpowiedź na pytania, czy pieniądz rzeczywiście jest nośnikiem wartości i czy da się na gruncie Marksowskiej teorii stworzyć czystą teorię pieniądza kredytowego przystosowaną do rzeczywistości fiat money (Moseley 2005, 9-17).

Odpowiedź Moseleya brzmi: nośnik wartości jako taki nie musi sam posiadać wartości. Zatem niewymienialny pieniądz papierowy, niemający pokrycia w żadnym kruszcu (tożsamy z czartalistowskim żetonem) teoretycznie sam może być nośnikiem wartości. W tym celu musi być uznawany przez właścicieli towarów za uniwersalny ekwiwalent, a co za tym idzie - musi być wymienialny na wszystkie dostępne towary. Powstaje wówczas następujące pytanie: jeżeli społecznie niezbędna praca jest reprezentowana przez niewymienialny na złoto pieniądz papierowy, to co w takim razie, w gospodarce ujmowanej jako całość, określa sumę 
pieniędzy odpowiadająca godzinie pracy społecznie niezbędnej, kiedy nie można przyrównać jej do godziny przeznaczonej na produkcję złota?

Według autora sedno problemu tkwi w tym, że w Marksowskich analizach pieniądza papierowego złoto jest niczym więcej, jak tylko medium zapośredniczającym pewną liczbę godzin pracy społecznie niezbędnej w relacji do ilości pieniędzy papierowych znajdujących się w obiegu. Wychodząc od analiz zawartych w Kapitale, pieniężne odzwierciedlenie czasu pracy (MELT - monetary expression of labour time) można by wówczas opisać prostym równaniem, w którym ilość pieniędzy znajdująca się w obiegu całej gospodarki dzieli się przez łączną sumę społecznie niezbędnego czasu pracy skonsumowanego przez tę gospodarkę w danym okresie. Innymi słowy, w odróżnieniu od czasów Marksa, wartość pieniądza byłaby dziś bezpośrednio wyznaczana przez czas pracy, bez mediacji kruszców. Koncepcja Moseleya zbliża się wobec tego do ilościowej teorii pieniądza w tym sensie, że ilość pieniądza w obiegu ma częściowy wpływ na ceny. Jednocześnie jest to teoria bardziej rozbudowana. Ilość pieniądza w obiegu nie przekłada się bezpośrednio na ceny. Są one wyznaczane w większym stopniu przez MELT: kiedy nominalna wartość pieniędzy znajdujących się w obiegu zaczyna przekraczać wartość pracy zawartej w dostępnych towarach, wówczas siła nabywcza pieniądza powinna maleć (Moseley 2011).

W zbliżony sposób rozumuje John Weeks, choć dla niego „towarowość” teorii pieniądza warta jest zachowania, gdyż jego zdaniem jest ona w stanie determinować bezwzględny poziom cen w gospodarce kapitalistycznej. W swoich analizach pokazał on, że towarowa baza pieniądza stanowi kotwicę nominalną dla poziomu cen towarów znajdujących się na rynku, tzn. stanowi zmienną nominalną, wedle której można badać odchylenia zagregowanego poziomu cen od zagregowanej wartości czasu pracy zgromadzonej w towarach. Na przykład z historycznej perspektywy można dostrzec korelację pomiędzy wzrostem zagregowanego indeksu cen w USA a spadkiem wydobycia złota na świecie. Nie znaczy to rzecz jasna, że wydobycie i ceny złota tłumaczą fluktuacje cen w USA i należy powrócić do standardu kruszcowego. Zdaniem Weeksa wskazuje to, że hipotetyczny towar pełniący rolę uniwersalnego ekwiwalentu, taki jak złoto, w praktyce może stanowić dla cen kotwicę nominalna. Nie tłumaczy to jednak, czy istnieje korelacja pomiędzy miarą wartości złota a cenami nominalnymi. Nie wyjaśnia także relacji między wartością złota a ceną złota w niewymienialnej walucie papierowej. Zatem nie wyjaśnia również związku pomiędzy ceną złota a ceną towarów w systemie fiat money (Weeks 2012). Autor chciał jedynie potwierdzić 
przeświadczenia Marksa z III tomu Kapitału, gdzie deklarował on, że choć system pieniądza kredytowego może opierać się głównie na wierze, to jednak nie może być w pełni oderwany od swojej towarowej, opartej na pracy społecznej bazy (Marks 1959, 163).

Powyższe analizy w głównej mierze miały za zadanie pokazać aktualność prawa wartości we współczesnej gospodarce kapitalistycznej. Mimo że stopy rentowności osiagane przez kapitalistów np. na drodze inwestycji w sektorze finansowym, a także za sprawa znajdującego się w obiegu pustego pieniądza mogą radykalnie przekraczać wartość zagregowanego społecznie niezbędnego czasu pracy, to jednak, jak pisał Michel Husson, zdarza się czasami, że gospodarka zostaje „przywołana do porządku przez prawo wartości”. Świadczyć o tym mają krachy na giełdzie, podczas których pieniądz wyparowuje z rynku, tzn. podczas których kurs akcji znacznie przekracza realną stopę zysku w marksistowskim rozumieniu (Husson 2011, 39).

Tytułem komentarza można więc stwierdzić, że Marksowskie czy marksistowskie ujęcie pieniądza nie stoi w bezpośredniej sprzeczności z czartalistowską teoria pieniądza, będąca podstawą MMT. Marksistowscy ekonomiści nie wykluczaja w żaden sposób, że gospodarka kapitalistyczna może ze względnym powodzeniem funkcjonować w systemie fiat money, zaś kapitaliści i rząd moga dokonywać inwestycji za pomoca pieniądza wykreowanego ex nibilo, a nawet osiagać $z$ tego tytułu wysoką stopę zwrotu z zainwestowanego kapitału. Nie upierają się również przy tezie, że cena waluty powinna być powiązana ze standardem kruszcowym.

Główna różnica polega na tym, że dla marksistów pieniądz - bez względu na to, jaka jego ilość znajduje się w obiegu - na ogólnym, zagregowanym poziomie posiada pewną wartość, która powinna odpowiadać wartości pracy abstrakcyjnej zawartej w wyprodukowanych towarach. Znaczące odchylenia od tej zasady teoretycznie powinny grozić kryzysem. Dla zwolenników MMT wartość pieniądza jest w dużej mierze umowna i zależna od zaufania, jakim obywatele darzą rząd, jego pozycji międzynarodowej itd. Jednocześnie w tym miejscu różnica między marksizmem a MMT nie jest tak duża, jak można by sądzić. Główny ekonomista i ideolog MMT, Randall Wray przyznał (z dość pragmatycznych powodów), że dla stabilności waluty potrzebne jest odniesienie do jakiejś formy kotwicy nominalnej (2013).

Związki ekonomii marksistowskiej i MMT mogą być więc bliższe, niż się wydaje. Stosunek zwolenników MMT do pieniądza jest w dużej mierze instrumentalny i naznaczony 
pragmatyzmem. Interesuje ich głównie efektywne wykorzystanie MMT jako narzędzia skutecznej polityki fiskalnej i kwestią drugorzędną wydaje się dla nich to, czy pieniądz jest nominalnie zakotwiczony w jakiejś bazie towarowej. Ekonomia marksistowska nie neguje rzeczywistości opisywanej przez MMT, lecz nie zatrzymuje się na powierzchownych efektach makroekonomicznych, tylko próbuje zbadać całą sprawę dużo głębiej. Mimo pozornie diametralnie różnego oglądu natury pieniądza w rzeczywistości obie szkoły ekonomiczne zgodne są ze sobą co do głównej konkluzji: bazująca na koncepcji egzogeniczności pieniądza neoliberalna polityka pieniężna jest zawodna, prawdziwe osiagi gospodarcze nie są zależne od ilości pieniądza znajdującego się w obiegu w takim stopniu, jak to przedstawia ekonomia neoklasyczna; kondycja gospodarcza i dobrobyt społeczeństwa zależne są od realnie wyprodukowanych dóbr i usług. Wartość pracy nie musi mieć bezpośredniego przełożenia na ceny. Pozwala jednak ocenić rzeczywisty stan gospodarki oraz ustalić stopę wyzysku kapitalistycznego.

Wobec powyższych wniosków warto zestawić główne cechy pieniądza według obydwu omawianych podejść:

\begin{tabular}{|c|c|c|}
\hline Pieniądz & Według MMT & Według marksizmu \\
\hline Charakter & Endogeniczny & Endogeniczny \\
\hline Forma & Kupon & Towar \\
\hline Wartość & $\begin{array}{l}\text { Umowna (zależna od zaufania } \\
\text { społecznego itd.) }\end{array}$ & $\begin{array}{l}\text { Na zagregowanym poziomie } \\
\text { odpowiada wartości pracy } \\
\text { zużytkowanej na produkcję } \\
\text { towarów }\end{array}$ \\
\hline $\begin{array}{l}\text { Stabilizacja waluty przez } \\
\text { kotwicę nominalną }\end{array}$ & Tak & Tak \\
\hline
\end{tabular}

Tabela nr 2. Gtówne cechy pieniadza wedtug Modern Monetary Theory i wedtug marksistowskiej krytyki ekonomii politycznej

Źródto: opracowanie wtasne 
Widać więc, że podejście obu szkół do praktycznych aspektów funkcjonowania pieniądza w gospodarce kapitalistycznej jest w zasadzie zbieżne. Zarówno marksiści, jak i MMT-erzy wykluczają neutralny charakter pieniądza, uznając jego endogeniczność. Ponadto neguja założenia ilościowej teorii pieniądza, jeżeli chodzi o inflacją, przy czym zgadzają się co do konieczności istnienia pewnego stabilizatora waluty w postaci kotwicy nominalnej. Można powiedzieć, że różnice przeniesione są na wyższy poziom - choć panuje względna zgoda co do tego, jakie pieniądz ma właściwości w powszednim żywocie gospodarki kapitalistycznej, to różnice pojawiaja przy teoretycznych rozważaniach nad rzeczywistą formą i wartością pieniądza. Marksizm cechuje się tutaj pogłębiona perspektywa, podczas gdy MMT przyjmuje najprostsze nasuwające się wytłumaczenie. Pod tym względem marksizm wydaje się bardziej wyrafinowana propozycją teoretyczna, jako że MMT raczej nie ma takich aspiracji i stawia na ujęcie bardziej pragmatyczne. Trzeba bowiem pamiętać, że przyjęcie lub modyfikacja klasycznej marksowskiej koncepcji pieniądza, choć pozwala zrozumieć głębiej system kapitalistyczny, nie ma dużego znaczenia praktycznego. Pomijając bardzo wysoki stopień jej abstrakcyjności (Nelson 2001), dość trudno byłoby za jej pomoca przeprowadzać szczegółowe badania empiryczne, np. systemu finansowego, w dużej mierze ze względu na statystyki, które są konstruowane bez żadnego związki z teorią wartości. Marksowska teoria pieniądza z pewnościa ma teoretyczna przewage nad neoklasyczną koncepcją ilościowa. Jej wykorzystanie empiryczne byłoby jednak nader trudne, zwłaszcza że we współczesnym świecie analizowanie pieniądza jako towaru postrzegano by jako działanie dość kuriozalne?

\section{Problem dynamiki gospodarczej}

Podstawą MMT w kwestii teorii dynamiki gospodarczej jest założenie zasadniczo tożsame z założeniami teorii keynesowskiej, a zwłaszcza postkeynesowskiej - gospodarka kapitalistyczna nie kreuje w automatyczny sposób pełnego zatrudnienia. Kluczową rolę w tym względzie odgrywa efektywny popyt zarówna na krótszą, jak i na dłuższą metę (Arestis 1996). W odróżnieniu od neokeynesistów zwolennicy MMT nie uważają, że przyczyną braku pełnego zatrudnienia w gospodarce kapitalistycznej moga być sztywne ceny lub płace.

7 Przedstawiliśmy zresztą pewien wycinek dyskusji, która trwa od lat i która dotyczy również możliwości wykorzystania Marksowskiej teorii kapitału pieniężnego, w tym zwłaszcza ustaleń dotyczących stopy procentowej we współczesnej ekonomii heterodoksyjnej. Wydaje się, że dyskusja ta wciąż jest daleka od zakończenia (zob. np. Fine 1985-1986, Lapavitsas 1997, Fine i Lapavitsas 2000, Dymski 2006). 
Jednocześnie można pobudzić jej wzrost i uniknąć kryzysu, stymulując ją inwestycjami finansowanymi kredytami i zwiększonym deficytem budżetowym.

Założenia te przeczą rzecz jasna ortodoksyjnie marksistowskim tezom, zgodnie z którymi kryzys, a w niektórych interpretacjach nawet całkowite załamanie gospodarcze, jest $z$ natury wpisany $w$ kapitalistyczny sposób produkcji i właściwie nie ma przed nim ratunku. Sprawa jest dość dobrze znana, więc ograniczymy się głównie do krytyki tych ortodoksyjnych założeń za pomoca teorii dynamiki gospodarczej Michała Kaleckiego (1980a) i współczesnej modyfikacji Marksowskich schematów reprodukcji autorstwa Andrew Trigga (2006).

Jak wiadomo, główny zarzut stawiany Marksowskiej teorii reprodukcji rozszerzonej kapitału społecznego (Marks 1955, 521-561) jest związany z problemem, skąd w schematach reprodukcji bierze się zbyt na towary będące efektem ciągle rosnącej produkcji kapitalistycznej. Jako jedna z pierwszych zagadnienie to podjęła Róża Luksemburg, która stwierdziła, że kapitaliści zapewniają sobie rosnący, efektywny popyt na towary poprzez kolonizację i transformację krajów niekapitalistycznych. Gdyby było inaczej i kapitalizm stanowiłby gospodarkę zamkniętą, wtedy - zdaniem polskiej marksistki - w zgodzie z logiką teorii reprodukcji kapitalizm czekałby krach i całkowite załamanie. Jednocześnie w swoich analizach militaryzmu Luksemburg antycypowała teorię interwencjonizmu państwowego, który miał w przyszłości uratować wzrost gospodarczy w kapitalizmie, choć podkreślała przy tym, że interwencja musi negatywnie odbić się na zarobkach robotników (2011, 563-564).

Zagadkę kapitalistycznej reprodukcji rozwiązał dopiero Kalecki. Ciągle rozwijającą się pomimo strukturalnych ograniczeń efektywnego popytu akumulację kapitału da się dość łatwo wyjaśnić, odwołując się do równań zysku z Teorii dynamiki gospodarczej. Jak wiemy, w równaniach polskiego ekonomisty następuje odwrócenie znanej z ekonomii klasycznej relacji pomiędzy oszczędnościami i inwestycjami:

\section{$\mathrm{S}<=$ I}

Czyli przyszłe oszczędności sektora prywatnego są wyznaczane przez bieżące inwestycje. Założenie to przyjmują w pełni wszystkie odłamy postkeynesizmu, w tym MMT. W całości równanie zysków przybiera następująca postać: 


\section{$\mathbf{P}=\mathrm{C}_{\mathbf{P}}+\mathrm{I}+\mathrm{BD}+\mathbf{N X}$}

gdzie P - zagregowane zyski, $C_{\mathrm{P}}$ - zagregowana „konsumpcja kapitalistów” (konsumpcyjne wydatki z zysku kapitalistów), I - inwestycje brutto całego sektora prywatnego (do tego agregatu wliczane są zwykle także zakupy nieruchomości przez osoby indywidualne), BD - deficyt budżetowy, NX - eksport netto (w przypadku nadwyżki importu wartość ta będzie ujemna). Wszystkie wartości odnoszą się do jednego, konkretnego okresu, np. jednorocznego.

W czasach Kaleckiego zakładano, że stopę oszczędności robotników można wyłączyć z modelu ze względu na jej niewielką istotność. Niektórzy ekonomiści głównego nurtu krytykowali tę teorię, twierdząc, iż jest ona nieaktualna, ponieważ współcześni robotnicy potrafia stosunkowo dużo oszczędzać i akumulować bogactwo. W rzeczywistości oznacza to dodanie tylko kolejnej zmiennej do równania $-\Delta \mathbf{S}_{(\mathbf{W})}$.

Innymi słowy, jest to relacja oszczędności względem zadłużenia netto gospodarstw domowych. Wzrost tych oszczędności oznacza spadek zysków, analogicznie spadek oszczędności oznacza wzrost zysków. Zatem:

$$
\mathbf{P}=\mathrm{C}_{\mathrm{p}}+\mathrm{I}+\mathrm{BD}+\mathrm{NX}-\Delta \mathrm{S}_{(\mathrm{W})}
$$

Kalecki wyjaśnił więc, że w otwartej gospodarce kapitalistycznej występuje cały szereg zmiennych umożliwiających reprodukcję rozszerzona. Źródłem zwiększonego efektywnego popytu na towary produkowane przez kapitalistów może być głównie: a) interwencja państwa finansowana z deficytu budżetowego, b) wzrost eksportu czy c) wzrost zadłużenia gospodarstw domowych. Można mówić też o czynnikach pomniejszych, jak wzrost konsumpcji samych kapitalistów, przy czym przeważnie nie przypisuje się temu czynnikowi zbyt wielkiej wagi, jako że zakłada się, iż poziom konsumpcji tej klasy jest w miarę stały i niezależny od poziomu zysków. Ewentualny wzrost wydatków kapitalistów będzie dotyczyć ograniczonego segmentu towarów, przeważnie dóbr luksusowych, co nie prowadzi jednak do znaczących fluktuacji w ich ogólnym poziomie konsumpcji.

Powyższe założenia nie budzą większych kontrowersji w ramach ekonomii heterodoksyjnej i sa przyjmowane przez jej przedstawicieli, w tym przez znaczną część ekonomistów marksistowskich. Bardziej skomplikowane jest zagadnienie sformułowanego przez Marksa prawa tzw. tendencji spadkowej stopy zysku. Kwestia tego, czy rzeczywiście 
prawo to jest aktualne, pozostaje jedna z linii demarkacyjnych wyznaczająca podziały we współczesnej ekonomii marksistowskiej.

Również w przypadku tego prawa Kalecki przeprowadził pionierską krytykę (Vianello 1989), dlatego też mówi się niekiedy, że zapoczątkował on ekonomię neomarksistowską, czyli wersję marksizmu, która w kwestiach spojrzenia na dynamikę gospodarczą i roli efektywnego popytu bliska jest ekonomii postkeynesowskiej.

Dla Marksa stopa zysku była siłą napędową całej gospodarki kapitalistycznej. Jednocześnie zdawał on sobie sprawę, że stopa zysku jest zagrożona przez sam rozwój produkcji (Marks 1959, 278-279). Postęp techniczny w kapitalizmie miał powodować spadek przeciętnej stopy zysku, ponieważ wraz z nim rośnie wydajność pracy, wobec tego ta sama ilość pracy będzie w przyszłości prowadziła do wytworzenia większej ilości lepszych produktów. W koncepcji Marksa rosnąca wydajność pracy wiąże się ze zmniejszeniem stopy wyzysku, co oznacza mniejszy zysk, a to powinno prowadzić do kryzysu kapitalizmu.

Problemem w tej koncepcji jest założenie, że podczas gdy organiczny skład kapitału zwiększa się (rośnie ilość środków produkcji w stosunku do zaangażowanej siły roboczej), to stopa wartości dodatkowej pozostaje niezmienna. Innymi słowy, wzrost wydajności pracy w kapitalizmie przekładałby się liniowo na wzrost płac robotników, doprowadzając do zmniejszenia zysków przedsiębiorców. Założenie to zostało uznane przez neomarksistów za mało realistyczne, a prawo spadkowej tendencji stopy zysku - odrzucone. Najbardziej charakterystyczna wydaje się w tym miejscu krytyka tego prawa, jakiej dokonał Paul Sweezy:

\begin{abstract}
W ustroju kapitalistycznym rosnącej wydajności pracy towarzyszy zwykle tworzenie się rezerwowej armii przemysłowej, której istnienie działa zniżkowo na płace, a więc zwyżkowo na stopę wartości dodatkowej. Jedna ze specyficznych cech kapitalizmu polega właśnie na tym, że praca nagromadzona w formie kapitału stałego staje do konkurencji z pracą żywą i hamuje żądania pracy żywej. Założenie stałej stopy wartości dodatkowej przy wzrastającej wydajności pracy oznacza niedocenienie tej właściwości ustroju kapitalistycznego (Sweezy 1961, 160).
\end{abstract}

Przyglądając się powyższej argumentacji Sweezy’ego, można stwierdzić, że dla nieortodoksyjnych marksistów działanie prawa zniżkowej tendencji stopy zysku jest de facto uzależnione od konkretnej, historycznej fazy kapitalizmu i siły klasy robotniczej. 
Mówiąc ściślej, to walka klas decyduje o tym, czy stopa zysku będzie rzeczywiście maleć, czy też wzrastać, co zresztą jest raczej zgodne z intencjami samego Marksa. Głębokie znaczenie walki klas w tym aspekcie podkreślał również Kalecki, który zakładał, że przy słabej pozycji związków zawodowych kapitaliści mogą podwyższać marże zysków kosztem konsumpcji samych robotników (1980b, 133).

Do problemu można podejść również bardziej matematycznie. Najbardziej doniosłej próby symulacji oddziaływania spadkowej tendencji stopy zysku na gospodarkę kapitalistyczną podjął się inny wybitny, nieco zapomniany polski ekonomista Henryk Grossman. Z jego obliczeń obejmujących trzydziestopięcioletni okres wynika, że na końcu cyklu gospodarka kapitalistyczna uległaby załamaniu, ponieważ zyski kapitalistów byłyby tak małe, że zabrakłoby im w końcu środków na inwestycje (Grossman 1929).

Grossman zakładał jednak neoklasyczne pryncypium, zgodnie z którym kapitaliści, żeby mogli zainwestować, muszą najpierw zgromadzić odpowiednią sumę oszczędności. Jak zauważył Trigg, sytuacja zmieni się znacząco, jeżeli do modelu Grossmana dodamy założenie Kaleckiego o inwestycjach determinujących oszczędności. Wówczas stopa zysku w tym modelu nadal będzie spadać, ale ze względu na dodane, odpowiadające współczesnym realiom założenie o możliwości kredytowania inwestycji - choć gospodarka może co prawda popaść w stagnację - reprodukcja rozszerzona nie zostanie zahamowana (Trigg 2006, 78-85).

Podobnie rzecz wygląda w przypadku makrodynamiki Kaleckiego. Należy zacząć od wzoru na stopę zysku z zainwestowanego kapitału:

$$
\mathbf{r}=\mathbf{P} / \mathbf{K}
$$

gdzie P - (zagregowane) zyski, K - wartość kapitału zaangażowanego w produkcję/usługi.

Zatem w kontekście równania zysków będzie to wyglądać tak:

$$
\mathbf{r}=\left(\mathrm{C}_{\mathrm{P}}+\mathrm{I}+\mathrm{BD}+\mathrm{NX}-\Delta \mathrm{S}_{(\mathrm{W})}\right) / \mathrm{K}
$$

W związku z tym inwestycje przekładają się na wartość kapitału:

$$
\mathbf{K n}=\mathbf{K}_{\mathbf{n}-1}+\mathbf{I}-\delta
$$


gdzie Kn - wartość bieżąca kapitału, $\mathrm{K}_{\mathrm{n}-1}$ - wartość kapitału w poprzednim okresie, $\delta$ - amortyzacja - odpisy/utrata wartości kapitału zaangażowanego w produkcję wynikające ze zużycia (fizycznego, ale także technologicznego).

Czyli w skrócie:

$$
\Delta \mathrm{K}=\mathbf{I}-\delta
$$

Jeżeli założyć więc, że wartości $\mathrm{C}_{\mathrm{p}}, \mathrm{BD}, \mathrm{NX}$ i $\mathrm{S}(\mathrm{W})$ będa równe zeru, to przyjmując przykładowo, że początkowy $\mathrm{K}=1000$ jednostek, przy $\delta=0, \Delta \mathrm{K}=\mathrm{I}=100$, zauważymy, że:

okres n: $\mathbf{r}=100 / 1000$; okres $\mathbf{n}+1: \mathbf{r}=100 / 1100 ; \mathbf{n}+2:$ 100/1200 itd... (Winczewski 2015).

Widać zatem na powyższych równaniach, że w przypadku uproszczonego, zamkniętego modelu gospodarki kapitalistycznej założenia Marksa dotyczące stopy zysku mają sens. Gdyby nie duży wpływ czynników zewnętrznych, gospodarka kapitalistyczna wykazywałaby silną tendencję stagnacyjną.

W praktyce w marksistowskiej ekonomii prowadzi się wiele badań empirycznych, które w zależności od przyjętej metodologii i danych statystycznych bądź potwierdzaja, bądź zaprzeczają istnieniu spadkowej tendencji stopy zysku w danych okresach.

Do pierwszej grupy należą między innymi badania Anwara Shaikha (1987), który odróżnia ogólną stopę zysku od stopy zysku przedsiębiorstw i koncentruje się na tendencji spadkowej tej drugiej. Podobne stanowisko zajmuje również Moseley, skupiający się z kolei na rosnącym znaczeniu i kosztach pracy nieprodukcyjnej, która wypiera pracę produkcyjna, przez co negatywnie oddziałuje na stopę zysku (1992, 2010). Najmocniejsze stanowisko zajmuje Andrew Kliman, który przewidywał, że po kryzysie finansowym 20072008 mimo pakietów stymulacyjnych stopa zysku będzie dalej spadać i prowadzić do stagnacji (2009).

$\mathrm{Na}$ drugim biegunie znajduje się przede wszystkim szkoła skupiona wokół czasopisma Monthly Review, wiele zawdzięczająca teorii dynamiki Kaleckiego. Oprócz wspomnianego wcześniej Paula Sweezy'ego do jej głównych przedstawicieli można zaliczyć Paula Barana, Harry’ego Magdoffa czy Johna Bellamy’ego Fostera. Według reprezentantów tej szkoły główną przyczyną obecnej stagnacji kapitalizmu nie jest spadek stopy zysku, lecz monopolizacja, która prowadzi do osłabienia konkurencji cenowej i zmniejszenia liczby innowacji (Baran i Sweezy 1966; Foster i Magdoff 2009). 
Rozwikłanie tego sporu wykracza poza ramy niniejszego artykułu ${ }^{8}$. Jego obecność pokazuje jednak, że w marksizmie nie istnieje jednolite, dogmatyczne podejście do dynamiki gospodarczej kapitalizmu. Okresowe występowanie efektu spadkowej stopy zysku jest dla marksistów kwestią badań empirycznych oraz stanu walki klasowej w danym czasie.

Zaprezentowaliśmy ten krótki przegląd wybranych stanowisk zajmowanych przez marksistowskich ekonomistów wobec dynamiki gospodarczej, aby pokazać, że w tym zakresie zasadniczo jest to teoria znacznie głębsza i bogatsza niż propozycje teoretyków związanych z MMT.

Co do dynamiki gospodarczej, zwolennicy MMT nie maja zbyt wiele do powiedzenia ponad to, co głosili Kalecki czy Keynes. Właściwie można uznać, że teoria ta niespecjalnie interesuje się dynamika gospodarczą, ufając raczej tradycyjnym postkeynesowskim założeniom.

Zasadne jest przypuszczenie, że ekonomiści związani z MMT zauważają stagnacyjną tendencję dynamiki kapitalizmu, przynajmniej w jego neoliberalnej wersji. Większość z nich zakłada wzrost gospodarczy oparty na rosnącym w kontrolowanym tempie długu publicznym. W przypadku braku środków inwestycyjnych zakłada się możliwość cięć w niektórych obszarach lub zwiększenie podaży suwerennej waluty wedle poniższego wzorca agregatu przepływów pieniężnych:

$$
Y(t)=M(t) v(t)
$$

gdzie Y oznacza wzrost PKB w okresie rocznym, M oznacza sumę zagregowanych zasobów pieniężnych, v oznacza zaś szybkość obiegu pieniężnego.

W przeciwieństwie do teorii neoklasycznej, która skupia się na wartości M, czyli ilościowym wyrazie zasobów pieniężnych, MMT koncentruje się na prędkości, z jaką pieniądze krążą w obiegu, starając się do tego wskaźnika dopasować podaż pieniądza (Andresen 2013).

8 W naszym przekonaniu należy jednak być podejrzliwym wobec badań niektórych ekonomistów, którzy próbując udowodnić aktualność założeń Marksa, dobierają próbę statystyczną od zakończenia II wojny światowej, czyli od 1945 roku, po współczesność. Ze względu na boom powojennej odbudowy powinno się raczej założyć, że stopa zysku znajdowała się wówczas na nienaturalnie wysokim poziomie, wobec czego logicznie rzecz biorą, musiał nastapić jej spadek. Dużo ciekawsze byłyby badania nad znacznie dłuższym okresem, obejmujące także dziewiętnasty wiek. Po za tym badania niektórych niemarksistowskich ekonomistów dowodzą, że sytuacja w gospodarce kapitalistycznej jest na tyle dynamiczna, iż trudno jest właściwie mówić o jakiejś jednolitej tendencji, jeżeli chodzi o stopę zysku (zob. np. Lee 1994). 
Generalnie neoczartaliści dość optymistycznie zakładają, że można osiagnnąć stabilny wzrost, rolując dług publiczny w nieskończoność. Tę intuicję potwierdzają badania ekonometryczne niektórych postkeynesistów, np. Steve’a Keena, który udowadniał, że możliwy jest stabilny wzrost oparty na ciągłym przedłużaniu spłaty zadłużenia publicznego (2000). W zgodzie z tą teorią są również tezy Michaela Hudsona, który proponował jakiś czas temu, aby wszystkie długi na świecie anulować (2014).

W MMT priorytetem jest pełne zatrudnienie, które ma być gwarantem pozytywnego rozwoju gospodarczego. Dlatego też zwolennicy MMT sceptycznie podchodzą dowskaźników wzrostu gospodarczego, które są „pompowane” spekulacją na rynkach finansowych. Wray otwarcie głosi, że jedna z cech jego teorii jest zerwanie z fetyszem PKB (i ogólnie wysokiej rentowności) oraz typowym dla ekonomii neoklasycznej powiązaniem pełnego zatrudnienia z dużym wzrostem gospodarczym (Wray i Tymoigne 2013). Dla neoczartalistów nie wzrost gospodarczy, lecz odpowiednia polityka fiskalna jest metoda na osiagnięcie stabilności gospodarczej i zarówno późniejszego stabilnego rozwoju, jak i wzrostu gospodarczego, co omówimy szerzej w kolejnej części.

Recepty neoczartalistów na stabilny rozwój gospodarczy nie różnią się zasadniczo niczym od propozycji Kaleckiego, który również uważał, iż da się sfinansować pełne zatrudnienie deficytem budżetowym, a inwestycje publiczne nie będą wypierać inwestycji prywatnych (1980c). Jednocześnie, w przeciwieństwie do neoczartalistów, polski ekonomista wykazywał się daleko idącym realizmem, gdy przewidywał, że kapitaliści nie będą chcieli utracić kontroli nad zatrudnieniem i płacami, w związku z tym będą podejmować wszelkie środki, by przeciwdziałać reformie kapitalizmu (Kalecki 1980d).

Z perspektywy marksistowskiej MMT jest więc kolejną odmianą reformizmu, która dzieli wszystkie jego zalety i wady. Marksiści nie wierzą w stabilny rozwój gospodarczy, więc nie podzielają optymizmu neoczartalistów. Można jedynie spekulować, czy postulaty MMT są w ogóle możliwe do zrealizowania w ramach kapitalizmu i czy nie prowadza siła rzeczy do jakiejś formy socjalizmu rynkowego. To jednak wymaga wpierw szerszego spojrzenia na proponowane przez MMT rozwiązania fiskalne. 


\section{MMT i polityka gospodarcza w kapitalizmie}

Jeżeli przyglądamy się polityce fiskalnej proponowanej przez MMT z perspektywy marksistowskiej, to musimy raz jeszcze powrócić do kwestii samego pieniądza. Zwolennicy MMT rzecz jasna maja rację, głosząc, że we współczesnym systemie walutowym pieniądz może być kreowany w dowolnych ilościach. Państwo nie jest w stanie wyznaczyć wartości pieniądza (Lavoie 1992, 192-197). Rzeczą decydującą w tym wypadku jest zaufanie do waluty, co już w punkcie wyjścia premiuje silne państwa kapitalistyczne, takie jak USA. Generalnie rzecz biorąc, wydaje się, że żeby w ogóle mówić o szansach powodzenia polityki fiskalnej prowadzonej zgodnie z MMT, potrzebna jest oparta na zdrowych zasadach polityka inflacyjna, czyli odnosząca się do wspomnianej już wcześniej jakiejś wersji kotwicy nominalnej. Być może nawet neoczartaliści mogliby skorzystać z ustaleń ekonomii marksistowskiej i spróbować stworzyć projekt takiej kotwicy, czerpiąc z teorii wartości opartej na społecznie niezbędnym czasie pracy ${ }^{9}$.

Gdyby polityka gospodarcza nie miała żadnego odniesienia do realnej wartości kreowanej $\mathrm{w}$ produktywnych sektorach gospodarki kapitalistycznej, istniałoby poważne ryzyko wzrostu cen lub spadku stopy zysku. Rzecz jasna teoretycznie istnieje możliwość utrzymywania gospodarki w stanie pełnego zatrudnienia przy pomocy swobodnego kreowania przez rząd suwerennej waluty, która nie posiada zakotwiczenia w realnej wartości towarów. Działo się tak w gospodarkach państw, w których panował realny socjalizm.

W klasycznym modelu takiej gospodarki pieniądz nie posiada niemal żadnego związku z produkowanymi towarami. Jego podaż ustalana jest administracyjnie, a sam pieniądz jest praktycznie neutralny, niczym w założeniach neoklasycznych. Nie ma więc realnego oddziaływania na procesy gospodarcze (Ericson 1991). Jednak w praktyce pełne zatrudnienie (przynajmniej w statystykach) jest możliwe do utrzymania mimo rosnących niedoborów, stagflacji czy ogólnie fatalnego stanu gospodarki. Poniekąd dowodzi to

9 Zdaniem niektórych zwolenników MMT funkcję kotwicy antyinflacyjnej mógłby spełniać program gwarantowanego zatrudnienia. Mechanizm antyinflacyjny tego programu określono mianem Non-AcceleratingInflation-Buffer Employement Ratio (NAIBER). Został on opisany przez Billa Mitchella (Mitchell i Muysken 2008). Krytycy zarzucaja tej koncepcji, że w jej ramach kotwicę stanowi nie społecznie niezbędny czas pracy, lecz realny czas pracy wykonywanej $\mathrm{w}$ ramach programu gwarantowanego zatrudnienia. W zwiazzu $\mathrm{z}$ tym porównywalność godzin pracy jest jedynie postulowana, a stabilizacja wartości pieniądza zależna jest od dyscyplinujących mechanizmów kontroli w ramach programu gwarantowanego zatrudnienia, o ile, tak jak proponuja zwolennicy MMT, prace w ramach programu gwarantowanego zatrudnienia nie mają tworzyć towarów/usług na sprzedaż, by nie konkurować z sektorem prywatnym (zob. Szlinder 2017). 
formalnej słuszności MMT. Niemniej jednak w zderzeniu z kapitalistycznymi reformami rynkowymi tego rodzaju polityka musiała zaowocować wyraźnymi tendencjami kryzysowymi, ponieważ urealnienie cen odbywało się poprzez inflację (Kołodko 1989).

Z perspektywy marksistowskiej w przypadku MMT problematyczne jest również to, że podobnie jak inne nurty keynesizmu teoria ta proponuje rozwiązania cechujące się dbałością o interesy obydwu głównych klas, to znaczy troszczy się zarówno o kapitalistów, jak i robotników.

Za Guglielmo Carchedim możemy wyróżnić dwa rodzaje interwencji rządowej w keynesowskiej polityce gospodarczej: a) aktywność w obszarze redystrybucji i b) aktywność inwestycyjna. W przypadku redystrybucji mówi się o dwóch problemach. Pierwszy dotyczy standardowego zarzutu, że korzystna dla klasy robotniczej polityka (wyższe pensje, mniejsze podatki, pomoc socjalna itd.) może obrócić się przeciwko niej (czy przeciwko społeczeństwu w ogóle) w tej fazie dobrej koniunktury, w której gospodarka powinna ulec schłodzeniu w celu zapobieżenia niekorzystnym efektom inflacyjnym. Wówczas, jeżeli rząd będzie chciał utrzymać względnie wysoki poziom zadowolenia zarówno klasy robotniczej, jak i kapitalistów (jeżeli chodzi o opodatkowanie), będzie zmuszony dokonać cięć np. w sektorze opieki zdrowotnej czy pomocy społecznej.

Carchedi wysuną jeszcze jeden zarzut - kiedy w okresie kryzysowym rząd prowadzi politykę redystrybucyjną korzystną dla klasy robotniczej (wzrost płac netto), wówczas konsumpcja rośnie. Jednak zdaniem włoskiego marksisty nie musi prowadzić to do wzrostu produkcji, ponieważ konsumowane są wówczas te produkty, na które w początkowej fazie kryzysu brakowało popytu. Można jednak spierać się z tą opinią - co prawda zmagazynowane wcześniej dobra moga znikać, ale z drugiej strony wyższy poziom konsumpcji może przynajmniej utrzymać poziom produkcji sprzed kryzysu. Ponadto, nawet jeżeli produkcja zostanie zwiększona, to przy wysokich płacach stopa zysku kapitalistów będzie się obniżać, zniechęcając ich do rozwoju produkcji (Carchedi 2012). Wszystko więc wydaje się zależne od tego, jak długo kapitaliści będą chcieli ponosić koszty prorobotniczej polityki. Należy przy tym pamiętać, że nawet przy malejącej stopie zysku, ze względu na fakt zwiększenia produkcji, rosnąć może sama masa zysku. Dużą rolę w takim przypadku odgrywają koszty płacowe. Jest to także wątek w szerszej dyskusji na temat tego, co determinuje inwestycje aktualna dynamika sprzedaży (Kalecki) czy właśnie stopa zysku (Amit Bhaduri). 
W przypadku polityki inwestycyjnej argumentacja Carchediego jest dużo słabsza. Właściwie replikuje ona neoklasyczną krytykę keynesizmu, z tym że przeprowadzona jest z pozycji marksistowskich. Carchedi stwierdził właściwie, że klasyczna polityka keynesowska, polegająca na inwestycjach w sferze zatrudnienia i produkcji, wypycha inwestycje prywatne (sektor prywatny miałby tracić wówczas zyski i rezerwy wartości dodatkowej). W odniesieniu do proponowanego m.in. przez neoczartalistów rozwiązania, polegającego na zwiększeniu podaży pieniądza, Carchedi miał do powiedzenia tylko tyle, że rosnący dług trzeba będzie kiedyś spłacić, co oddala tylko kryzys w czasie. Jak wiemy, z perspektywy MMT jest to zwyczajny nonsens.

Inwestycje publiczne zmierzające do zwiększenia zatrudnienia i poprawienia warunków życia klasy robotniczej są rzeczą jak najbardziej pożądana. Proponowany przez MMT program gwarancji zatrudnienia - polegający na sfinansowaniu przez państwo każdemu chętnemu społecznie pożytecznego stanowiska pracy za minimalną stawkę ${ }^{10}$ - prowadziłby, parafrazując Keynesa, do „eutanazji drobnych przedsiębiorców”, a ściślej mówiąc, tych spośród nich, którzy swoją konkurencyjność opierają na niskich kosztach pracy.

Pomijając ewentualny opór kapitalistów, głównym problemem jest to, że polityka prowadząca do pełnego zatrudnienia oparta o tzw. monetyzację długu (czyli pokrywanie go przez bank centralny dodrukiem lub zapisami na kontach) nie została zweryfikowana w praktyce ${ }^{11}$. Jednocześnie występują w tym przypadku dość istotne komplikacje teoretyczne, których są świadomi sami zwolennicy MMT. Jeden z nich, Bill Mitchell przyznał, że przy polityce monetyzacji długu po osiagnięciu pełnego zatrudnienia ceny zaczną rosnąć (2013). To samo stwierdził keynesista Ed Dolan, przy czym powołując się na krzywą Phillipsa i badania statystyczne dotyczące powojennej gospodarki USA, doszedł do wniosku, że empirycznie rzecz biorąc, inflacja rosła, zanim jeszcze osiagnięto stan pełnego zatrudnienia (2013).

10 Program gwarantowanego zatrudnienia jest też zresztą często analizowany jako konkurencyjny dla dochodu podstawowego. Na ten temat toczyło się i toczy współcześnie wiele dyskusji (zob. np. Mitchell I Mosler 2001, Mitchell i Watts 2005, Jackson 1999, Manjarin i Szlinder 2016). Wśród ekonomistów heterodoksyjnych zdania na ten temat są podzielone. Tematowi temu został poświęcony również jeden z numerów Praktykei Teoretycznej: http://www.praktykateoretyczna.pl/numery/2017-2/pt-2242017/ .

11 Jednocześnie warto wspomnieć, że w ograniczonej skali testowano programy gwarantowanego zatrudnienia: 1. Expanded Public Works Program (EPWP) w RPA; 2. National Rural Employement Guarantee Act (NREGA) w Indiach; 3. Jefes de Hogar w Argentynie. Zwolennicy MMT często powołują się na te programy jako na przykłady umiarkowanego sukcesu. Inni ekonomiści jednak sa bardziej krytyczni i wymieniają wiele wad tych programów, zwłaszcza indyjskiego. 
Wydaje się więc, że nawet jeżeli proponowana przez neoczartalistów polityka inwestycyjna będzie przynosić pozytywne efekty, to jednak w końcu zacznie skutkować powrotem do problemów natury redystrybucyjnej. Żeby inflacja nie zniwelowała pozytywnych skutków rosnącego zatrudnienia, w pewnym momencie konieczny będzie nawrót do polityki schładzania, które w zależności od konfiguracji politycznej obozu rządzącego może oznaczać albo rozwiązania niekorzystne dla materialnego położenia klasy robotniczej, albo deprecjację stopy zysku kapitalistów, co z kolei może doprowadzić do załamania produkcji.

Trzeba pamiętać, że jest to jedynie pewien wycinek krytyki MMT, ponieważ ujęte zostały przez nas głównie argumenty ważne z perspektywy marksizmu. W łonie ekonomii postkeynesowskiej toczą się na temat MMT ostre spory, skupiające się na rozmaitych wadach tej teorii istotnych w optyce samego keynesizmu. Generalnie sami postkeynesiści krytykuja MMT za dość płytkie podejście do teorii Keynesa i niekonsekwentne trzymanie się jej (Lavoie 2011, Palley 2013). Jednocześnie warto pamiętać, że zwolennicy MMT bronią swoich pozycji (Fullwiler, Kelton i Wray 2012), choć zdaniem krytyków ich odpowiedzi opierają się w dużej mierze na powtarzaniu wciąż tych samych argumentów w nieco zmienionej formie.

\section{Polityczne konsekwencje MMT}

Pomijając rozważania stricte ekonomiczne, trzeba powiedzieć kilka słów o politycznym wymiarze tej teorii. Pomimo faktu, że podobnie jak większość postkeynesistów, większość neoczartalistów reprezentuje poglądy lewicowe i bliskie socjaldemokracji, to jednocześnie wielu z nich chwali MMT jako neutralna politycznie teorię dostępną dla każdego, bez względu na przekonania.

Założenie o politycznej neutralności (przynajmniej jeżeli chodzi o część deskryptywna tej teorii) jest przez sprzymierzeńców MMT uznawane za jej zaletę. W optyce marksistowskiej jednak jest to raczej dość naiwne i szkodliwe przekonanie. Deklarowanie neutralności wpisuje się w nurt określony przez Györgya Lukàcsa mianem dezideologizacji. W zamierzeniu miała ona na celu uniezależnienie nauki od wszelkiej ideologii, jednakże zdaniem autora w praktyce oznaczała eliminację z pola zainteresowań nauki problematyki moralnej, a także tematu problemów i konfliktów społecznych. Wywodząca się z neopozytywizmu koncepcja nauki miała zdaniem Lukàcsa wyzbyć się w ogóle wszelkich wartościowań (1984, 791-792). 
W rzeczywistości prąd nastawiony na kompletną dezideologizację nauki, a w dalszej perspektywie także kultury, polityki i społeczeństwa, sam musi być nazwany ideologia. Zwolennik teorii Lukàcsa powiedziałby, że ten styl uprawiania nauki jest w praktyce rodzajem usprawiedliwiania społecznego i kulturowego status quo.

Zapewne rzecznicy MMT liczą na marketingowy efekt przekazu o neutralności politycznej, licząc na to, że uda im się pozyskać sympatyków w szerokich kręgach społecznych i wśród polityków różnych opcji. Dotyczy to przede wszystkim części deskryptywnej MMT, która bez odwoływania się do żadnej ideologii opisuje funkcjonowanie współczesnych systemów monetarnych, rolę banków centralnych i komercyjnych, mechanizm kreacji pieniądza itd. Zdaniem Wraya część ta byłaby jak najbardziej do przyjęcia w warunkach wolnorynkowych. Spostrzeżenia te podzielają niektórzy libertarianie12. Można argumentować, że elementy normatywne, takie jak sztandarowy program gwarantowanego zatrudnienia, mają charakter jednoznacznie lewicowy, socjaldemokratyczny, a być może stanowią nawet jakiś krok w kierunku systemu socjalistycznego. Jednakże, po pierwsze, nie wiążą się one z koniecznością przewrotu w stosunkach produkcji, lecz z kolejną reforma, która może zostać zmodyfikowana lub po jakimś czasie cofnięta w wyniku zmiany układu sił klasowych. Po drugie, mimo że przypisuje się takim reformom socjaldemokratyczny charakter, to nie wydaje się, by były one w sposób konieczny i nierozerwalny związany z ogólną treścią polityki socjaldemokratycznej opartej na wierze w demokrację i wolności obywatelskie. Teoretycznie można wyobrazić sobie sytuację, w której reformy tego typu są realizowane przez państwa autorytarne, wykorzystujące gwarancje pracy dla każdego obywatela w sektorze publicznym w celu zwiększenia kontroli nad społeczeństwem.

Narzędzia wchodzące w skład MMT pozbawione politycznej treści mogą być wykorzystywane przez rozmaite nurty dalekie od idei postępu społecznego. Ponieważ neoczartalizm kładzie bardzo duży nacisk na suwerenność walutową oraz ścisłe podporządkowanie polityki monetarnej i fiskalnej aparatowi biurokratycznemu, to istnieje ryzyko wykorzystania jego postulatów przez stronnictwa nacjonalistyczne, konserwatywne, a nieraz wręcz faszyzujące, które hasło suwerenności fiskalnej i monetarnej mogą wpisać w szerszy dyskurs narodowo-konserwatywny, straszący społeczeństwo utratą suwerenności

12 Dowody na to znajdują się w blogosferze, zob. np. https://beinglibertarian.com/mmt/. 
narodowej w przypadku poparcia innej opcji politycznej. Istnieją zresztą takie przykłady wykorzystania MMT'13.

Innym problemem jest imperializm i możliwość wykorzystania własnej waluty przez kraje imperialistyczne w celu zdominowania państw słabszych. Temat ten zreszta jest w ostatnich latach szerzej dyskutowany. Stosunkowo niedawno Janis Warufakis w Globalnym Minotaurze opisywał, w jaki sposób USA, korzystając ze swojej politycznej, militarnej i gospodarczej przewagi, przez długi czas wykorzystywały kraje europejskie i azjatyckie w celu zapewnienia wysokich zysków swoim przedsiębiorstwom (2015). Podobnie Michael Hudson w swojej książce Super Imperialism zauważał, że USA zadłużając się, korzystaja z siły swojej waluty opartej na potencjale militarnym państwa, w ten sposób zapewniając sobie stały dopływ dóbr i usług stosunkowo niskim kosztem (2003).

Zwolennicy MMT bronią się, głosząc pogląd, że przecież USA w każdym momencie może spłacić wszystkie swoje długi (Martin 2014), generując dowolną ilość waluty w postaci zapisu na koncie. Jak już wspomniano wcześniej, wartość pieniądza w systemie fiat money opiera się przede wszystkim na wierze. Oprócz tego istotną rolę odgrywa popyt na daną walutę. Dlatego imperializm USA nie opiera się na tym, że zaciagają one długi, których nie mogą spłacić. Polega raczej na tym, że swoją siła niejako zmuszają inne kraje do uznawania dolara za główną walutę rezerwową. Wskutek tego zawsze będzie występowało zapotrzebowanie na tę walutę, przez co nie może ona w krótkim czasie ulec katastrofalnej deprecjacji. Druga stroną medalu jest fakt, że kraje słabsze gospodarczo, a mówiąc ściślej, kraje prowadzące niefrasobliwą politykę podatkową - nieposiadające skutecznego aparatu państwowego zapewniającego wysoką ściagalność podatków - oraz te o wysokim poziomie zadłużenia zagranicznego, nawet w teorii nie mogą w pełni wykorzystać oferty MMT, choćby i całkowicie kontrolowały podaż suwerennej waluty krajowej. Po pierwsze, jeżeli kraje te maja słaby i nieskuteczny aparat państwowy, to ich waluta nie będzie cieszyła się zaufaniem obywateli, nie mówiąc już o zagranicznych pożyczkodawcach. To zmusza je do zaciagania kredytów w obcych walutach, np. w dolarach czy euro. W związku z tym banki centralne obcych państw, manipulując kursem walut, moga w istotny sposób wpływać na sytuację gospodarczą, a przez to także na sytuację społeczno-polityczną danego kraju.

13 Chociażby w naszym kraju istnieje tzw. Instytut Nowoczesnej Teorii Monetarnej, który wykorzystuje tę teorię do głoszenia haseł nacjonalistycznych i antyimigranckich. 
Dobrze zresztą obrazuja to działania Europejskiego Banku Centralnego, a ściślej mówiąc - tzw. Troiki (EBC, Komisja Europejska, Międzynarodowy Fundusz Walutowy), które korzystając z obecności Grecji w strefie euro, wpływaja na jej politykę wewnętrzną i zmuszają jej rząd do posłuszeństwa oraz przeprowadzania „reform” w duchu polityki austerity. Grecy, nie posiadając własnej waluty, nie za bardzo moga się przeciwstawić dominacji Troiki. Oczywiście problematyczne jest to, czy wyjście ze strefy euro i powrót do drachmy poprawiłyby sytuację. Część ekonomistów jednak, w oparciu o powyższe przesłanki, popiera ten pomysł - np. Costas Lapavitsas (2012).

MMT, pretendująca do bycia teorią „uniwersalną” i „apolityczną”, ma więc różne oblicza. Z jednej strony, za jej pomocą można spojrzeć na imperializm z innej perspektywy. Z drugiej zaś strony, w teorię tę nie jest wpisana żadna głębsza analiza polityki i stosunków społecznych. Wobec tego istnieje realne niebezpieczeństwo jej wykorzystania w propagandzie czy nawet praktyce etatystycznych stronnictw prawicowych. Ponadto trzeba powiedzieć, że teoria ta implicite zakłada bardzo duże zaufanie do biurokracji państwowej, co może mieć różne negatywne skutki, włączając w to nadmierne korzystanie z procedury monetyzacji długu.

\section{Konkluzja}

Ogólnie rzecz biorąc, MMT i marksizm funkcjonują na nieco innych obszarach i poziomach współczesnej ekonomii. MMT trudno w ogóle nazwać ekonomia polityczną. Jest to raczej pewien zestaw narządzi ekonomicznych możliwych do wykorzystania przez polityków gospodarczych reprezentujących różne opcje (zarówno gospodarcze, jak i polityczne), choć zasadniczo jest przedmiotem uwagi głównie postkeynesistów i osób o zapatrywaniach socjaldemokratycznych.

Zasadniczo jednak istnieje pewna przestrzeń dialogu między MMT a ekonomią marksistowska. Stan badań pokazuje, że nie istnieje bezpośrednia sprzeczność między marksistowskim a neoczartalistowskim spojrzeniem na rolę pieniądza. Różnica polega na tym, że teoria marksistowska funkcjonuje na głębszym poziomie i nie poprzestaje na konstatacji faktów wynikających z rzeczywistości fiat money. Szuka ona realnych źródeł wartości pieniądza; wydaje się, że choć teoria wartości ma w praktyce dość ograniczone znaczenie, 
to jednak może ona stanowić bazę alternatywnej polityki monetarnej, oferując teoretyczną podstawę do wyznaczenia kotwicy nominalnej - jest to $\mathrm{z}$ pewnościa ten aspekt marksistowskiej teorii pieniądza, na który powinni zwrócić uwagę zwolennicy MMT.

W przypadku rozwiązań proponowanych przez MMT w obszarze polityki gospodarczej można stwierdzić, że w większości podlegają one tradycyjnej marksistowskiej krytyce keynesizmu, która zarzuca reprezentantom tego nurtu kolaborację klasowa, zaś same rozwiązania ocenia jako w dużej mierze nieskuteczne. Rzecz jasna wielu współczesnych marksistów popiera rozwiązania keynesowskie w zakresie redystrybucji, a zwłaszcza inwestycji, ponieważ dają one nadzieję na wzmocnienie roli klasy robotniczej. Jednocześnie marksiści zdają sobie sprawę, że pełna realizacja tych postulatów jest niemożliwa w ramach kapitalistycznego sposobu produkcji. Z perspektywy tradycyjnie marksistowskiej bez uspołecznienia sektora finansów i produkcji, bez wprowadzenia demokratycznego planowania gospodarczego, polityka ciagłego zwiększania wydatków musi zawieść. Niemniej jednak wydaje się, że niektóre rozwiązania proponowane przez MMT, jak np. monetyzacja długu, sa dla marksistów do zaakceptowania i warto je dokooptować do zestawu postulatów radykalnej lewicy.

Jednym z największych mankamentów MMT jest jej deklarowana apolityczność, i to w tym aspekcie ekonomia marksistowska ma nad nią największą przewage, ponieważ stanowi element kompleksowej teorii badającej przede wszystkim stosunki produkcji w kapitalizmie. MMT można uznać za pewną zredukowaną wersję keynesizmu, która odświeża kilka koncepcji ważnych dla ekonomii heterodoksyjnej. Jeżeli chodzi o aspekt normatywny, recepty tej teorii wydaja się mocno uproszczone i nacechowane raczej przesadnym optymizmem w kwestiach możliwości regulacji gospodarki kapitalistycznej. 


\section{Wykaz literatury}

Aldasoro, Ińaki i Robert Unger. 2017. „External Financing and Economic Activity in Euro Area - Why are Bank Loans Special?” BIS Working Papers 622.

Arestis, Philip. 1996. „Post-Keynesian Economics: Toward Coherence.” Cambridge Journal of Economics 20.

Andresen, Trond. 2013. „Improved Macroeconomic Control with Electronic Money and Modern Monetary Theory." Real World Economics Review 63.

Baran, Paul i Paul Sweezy. 1966. Monopoly Capital. New York: Monthly Review Press.

Bell, Stephanie. 2001. „The Role of the State and the Hierarchy of Money.” Cambridge Journal of Economics 25.

Bludnik, Izabela. 2015. Postkeynesižm. Teoria endogeničnej kreacji pieniadza. Poznań:

Wydawnictwo Uniwersytetu Ekonomicznego w Poznaniu.

Bransbourg, Gilles. 2011. „Fides et Pecunia Numerata. Chartalism and Metallism in the Roman World Part 1: The Republic." AJN Second Series 23.

Cambell, Martha. 2005. „Marx’s Explanation of Money Function: Overturning the Quantity Theory." W Marx on Money. Red. Fred Moseley. New York: Palgrave Macmilian.

Carchedi, Guglielme. 2012. „Could Keynes End the Slump? Introducing the Marxist Multiplier." International Socialism 136. http://isj.org.uk/could-keynes-end-the-slumpintroducing-the-marxist-multiplier/ .

Disyatat, Piti. 2010. „,The Bank Lending Channel Revisited.” BIS Working Papers 297.

Dolan, Ed. 2013. „Debt Sustainability, Growth, Interest Rates, and Inflation: Some Charts for Discussion and Some Inconvienient Truths for MMT." http://www.economonitor.com/dolanecon/2013/01/28/debt-sustainability-growthinterest-rates-and-inflation-some-charts-for-discussion-and-some-inconvenient-truthsfor-mmt/.

Domar, Evsey. 1962. Szkice z teorii wærostu gospodarczego. Tłum. Lech Niżyński. Warszawa: Państwowe Wydawnictwo Naukowe.

Dymski, Gary. 2006. „Money and Credit in Hetorodox Theory: Reflections on Lapavitsas.” Historical Materialism 14.

Ericson, Richard. 1991. „The Classical Soviet-Type Economy: Nature of the System and Implications of Reform." The Journal of Economic Perspectives 5.

Fine, Ben. 1985-1986. „Banking Capital and Theory of Interest.” Science \& Society 69.

Fine, Ben i Costas Lapavitsas. 2000. „Markets and Money in Social Science: What Role for Economics?" Economy and Society 29.

Fontana, Giuseppe. 2000. „Post Keynesians and Circuists on Money and Uncertainty: an Attempt at Generality." Journal of Post Keynesian Economics 23.

Fontana, Giuseppe. 2003. „Post Keynesian Approaches to Endogenous Money: a Time Framework Explanation." Review of Political Economy 15.

Forstater, Matthew. 2004. „Tax-Driven Money: Additional Evidence from the History of Thought, Economic History and Economic History". Working Paper 35. http://www.cfeps.org/pubs/wp-pdf/WP35-Forstater.pdf .

Foster, John i Harry Magdoff. 2009. The Great Financial Crisis. New York: Monthly Review Press.

Friedman, Milton. 1994. Intrygujacy pieniadz: Tłum. Krzysztof Szlichciński. Lódź: Wydawnictwo Lódzkie.

Friedman, Milton. 2010. „Quantity Theory of Money”. W Monetary Economics. Red. Steven Durlauf i Lawrence Blume. London: Palgrave Macmillan. 
Fullwiler, Scott T., Stephanie Kelton i L. Randall Wray. 2012. Modern Money Theory: A Reponse to Critics.

http://cas2.umkc.edu/economics/people/facultyPages/wray/papers/Working\%20Pap ers/Fullwiler\%20Kelton\%20Wray\%20MMT.pdf .

Grossman, Henryk. 1929. Das Akkumulations- und Zusammenbruchsgetz des kapitalistischen Systems. Leipzig: Verlag Neue Kritik.

Graziani, Augusto. 1997. „Marxist Theory of Money.” International Journal of Political Economy 27.

Gruszecki, Tomasz. 2015. „Problemy z rozumieniem współczesnego pieniądza.” Acta Universitatis Lodriensis. Folia Economica 317.

Hudson, Michael. 2003. Super Imperialism. London: Pluto Press.

Husson, Michel. 2011. Kapitalizm bez znieczulenia. Tłum. Zbigniew Marcin Kowalewski. Warszawa: Książka i Prasa.

Kapuściński, Mariusz, Andrzej Kocięcki, Halina Kowalczyk, Tomasz Łyziak, Jan Przystupa, Ewa Stanisławowska, Anna Sznajderska i Ewa Wróbel. 2016. „Mechanizm transmisji polityki pieniężnej w Polsce. Co wiemy w 2015 roku?”. Materialy i Studia NBP 323.

Jackson, William. 1999. „Basic Income and the Right to Work: A Keynesian Approach.” Journal of Post-Keynesian Economics 21.

Kalecki, Michał. 1980a. „Teoria dynamiki gospodarczej”. W Michał Kalecki. Drieła. T. 2. Warszawa: Państwowe Wydawnictwo Ekonomiczne.

Kalecki, Michał. 1980b. „Walka klas a podział dochodu narodowego”. W Michał Kalecki. Dzieła. T. 2. Warszawa: Państwowe Wydawnictwo Ekonomiczne.

Kalecki, Michał. 1980c. „Trzy drogi do pełnego zatrudnienia”. W Michał Kalecki. Drieła. T. 1. Warszawa: Państwowe Wydawnictwo Ekonomiczne.

Kalecki, Michał. 1980d. „Polityczne aspekty pełnego zatrudnienia”. W Michał Kalecki. Drieła. T. 1. Warszawa: Państwowe Wydawnictwo Ekonomiczne.

Keen, Steve. 2000. „The Nonlinear Economics of Debt Inflation.” W Commerce, Complexity and Evolution. Red. William Barnett. Cambridge: Cambridge University Press.

Keynes, John Maynard. 1930. A Treatise on Money. New York: Harcourt, Brace and Company.

Knapp, Georg. 1924. State Theory of Money. Tłum. H.M Lucas i J. Bonar. London: Macmillan \& Company Limited.

Kołodko, Grzegorz. 1989. „Economic Reforms and Inflation in Socialism: Determinants, Mutual Relationships and Prospects." Communist Economies 1.

Kubiczek, Sebastian. 2015. „Od barteru do pieniądza wirtualnego - charakterystyka procesu dematerializacji pieniądza”. Zeszyty Naukowe Uniwersytetu Ekonomicznego w Katowicach 236.

Lapavitsas, Costas. 1997. „Two Approaches to the Concept of Interest Bearing Capital.” International Journal of Political Economy 27.

Lapavitsas, Costas. 2012. Crisis in the Eurozone. London: Verso Books.

Lavoie, Don. 1986. „Marx, the Quantity Theory, and the Theory of Value.” History of Political Economy 18.

Lavoie, Marc. 1984. „The Endogenous Flow of Credit and the Post Keynesian Theory of Money." Journal of Economic Issues 18.

Lavoie, Marc. 1992. Foundations of Post-Keynesian Economic Analysis. Cheltencham: Edward Elgar.

Lavoie, Marc. 2011. „The Monetary and Fiscal Nexus of Neo-Chartalism: A Friendly Critical Look." https://www.boeckler.de/pdf/v_2011_10_27_lavoie.pdf.

Lerner, Abba. 1943. „Functional Finance and the Federal Debt.” Social Reasarch 10. 
Lee, Frederic. 1994. „From Post-Keynesian to Historical Price Theory.” Review of Political Economy 3.

Lukàcs, György. 1984. Wprowadẓenie do ontologii bytu społecznego. Tłum. Kazimierz Ślęczka. Warszawa: Państwowe Wydawnictwo Naukowe.

Luksemburg, Róża. 2011. Akumulacja kapitału. Tłum. zbiorowe. Warszawa: Książka i Prasa. Lagosz, Marek. 2012. Marks. Praca i czas. Warszawa: PWN.

Manjarin, Edgar i Maciej Szlinder. 2016. „A Marxist Argumentative Scheme on Basic Income and Wage Share in an Anti-Capitalist Agenda." Basic Income Studies 11.

Marks, Karol. 1953. Praycsynek do kerytyki ekonomii politycznej. Tłum. Edward Lipiński. Warszawa: Książka i Wiedza.

Marks, Karol. 1955. Kapitat. T. 2. Tłum. Julian Maliniak. Warszawa: Książka i Wiedza.

Marks, Karol. 1956. Kapitał. T. 1. Tłum. zbiorowe. Warszawa: Książka i Wiedza.

Marks, Karol. 1959. Kapitał. T. 3, cz. 2. Tłum. Edward Lipiński, Julian Maliniak. Warszawa: Książka i Wiedza.

Marks, Karol. 1986. Zarys krytyki ekonomii politycznej. Tłum. Jan Wyrozembski. Warszawa: Książka i Wiedza.

Martin, Peter. 2014. „Economic Imperialism: Fact or Fiction?” https://petermartin2001.wordpress.com/2014/06/09/economic-imperialism-fact-orfiction/.

McLeay, Michael, Amar Radia i Thomas Ryland. 2014. „Money Creation in Modern Economy." Bank of England Quaterly Bulletin 1.

http://www.bankofengland.co.uk/publications/Documents/quarterlybulletin/2014/q b14q1 prereleasemoneycreation.pdf.

Menger, Carl. 2007. Principles of Economics. Tłum. James Dingwall i Bert F. Hoselit: Auburn: Ludwig von Mises Institute.

Milios, John, Dmitri Dimoulis i George Economakis. 2002. Karl Marx and the Classics. Hampshire: Ashgate Publishing Company.

Mitchell-Ins, Alfred. 1914. „The Credit Theory of Money.” The Banking Law Journal 31.

Mitchell, Bill i Joan Muskyen. 2008. Full Employement Abandoned Shifting Sands and Policy Failures. Cheltencham: Edward Elgar.

Mitchell, Bill. 2009. „Deficit Spending 101 Part 1.” bttp:// bilbo.economicoutlook.net/ blog/? $p=332$.

Mitchell, Bill. 2009. „Deficit Spending 101 Part 3.” http:// bilbo.economicoutlook.net/blog/? $p=381$.

Mitchell, Bill. 2013. „Exploring Pro-Cyclical Budget Positions.” bttp:/ / bilbo.economicoutlook.net/blog $/$ ? $p=22542$.

Mitchell, William i Warren Mosler. 2001. „Fiscal Policy and Job Guarantee.” Australian National University Discussion Paper 441. https:/ / openresearchrepository.anu.edu.au/bitstream/1885/40582/3/DP441.pdf.

Mitchell, William i Martin Watts. 2005. „A Comparison of the Macroeconomic Consequences of Basic Income and Job Guarantee Schemes.” Rutgers Journal of Law \& Urban Policy 2.

Moseley, Fred. 1992. The Falling Rate of Profit in the Postwar United States Economy. New York: St. Martins Press.

Moseley, Fred. 2005. „Introduction.” W Marx's Theory of Money. Red. Fred Moseley. New York: Palgrave Macmilian.

Moseley, Fred. 2010. „Is the U.S Economy Headed for a Hard Landing?” Mount Holyoke College Working Paper

http://www.mtholyoke.edu/courses/fmoseley/HARDLANDING.doc 
Moseley, Fred. 2011. „The Determination of the »Monetary Expression of Labor Time» (»MELT «) in the Case of Non-Commodity Money". Review of Radical Political Economy 43.

Mosler, Warren. 2014. Siedem śmiertelnie niewinnych oszustw polityki ekonomicznej. Tłum. Mariusz Kuciel. Warszawa: Warszawski Instytut Nowoczesnej Teorii Monetarnej.

Nelson, Anitra. 2001. „Marx Theory of the Money Commodity.” History of Economics Review 31.

Palley, Thomas. 2013. „Money, Fiscal Policy, and Interest Rates: A Critique of Money Monetary Theory." IMK Working Paper 109. https://www.econstor.eu/bitstream/10419/105973/1/imk-wp_109_2013.pdf .

Ricardo, David. 1817. „Principles of Political Economy and Taxation.” https://www.marxists.org/reference/subject/economics/ricardo/tax/ch28.htm.

Semenova, Alla. 2011. „The Origins of Money: Evaluating Chartalist and Metallist Theories in the Context of Ancient Greece and Mesopotamia." https://mospace.umsystem.edu/xmlui/bitstream/handle/10355/10843/SemenovaOri MonEva.pdf.

Shaikh, Anwar. 1987. „Falling Rate of Profit and the Economic Crisis in the US.” W Imperiled Economy. Red. Robert Cherry. New York: Monthly Review Press.

Szlinder, Maciej. 2017. „Problemy z argumentacją zwolenników Nowoczesnej Teorii Pieniężnej przeciw dochodowi podstawowemu. Komentarz do tłumaczenia". Praktyłka Teoretyczna 24.

Sweezy, Paul. 1961. Teoria rozwoju kapitalizmu. Tłum. Edward Lipiński. Warszawa: Państwowe Wydawnictwo Naukowe.

Trigg, Andrew. 2006. Marxian Reproduction Schema: Money and Aggregate Demand in Capitalist Economy. New York: Routledge.

Umiński, Paweł. 2014. „Modern Monetary Theory jako alternatywne podejście do pieniądza i polityki pieniężnej”. Folia Oeconomica 299.

Warufakis, Janis. 2015. Globalny Minotaur. Tłum. Joanna Bednarek. Warszawa: PWN.

Vianello, Ferdinando. 1989. „Effective Demand and the Rate of Profit: Some Thoughts on Marx, Kalecki and Sraffa." W Kalecki's Relevance Today. Red. Mario Sebastiani. London: Palgrave Macmilian.

Weeks, John. 2012. „The Theory and Empirical Credibility of Commodity Money.” Science \& Society 76.

Winczewski, Damian. 2016. „Kryzys emerytalny w Unii Europejskiej”. Bez Dogmatu 109.

Winczewski, Damian. 2015. „Pieniądz i zagregowany popyt w polskiej ekonomii marksistowskiej”. Nowa Krytyka 35.

Wray, Randall. 1992. „Commercial Banks, the Central Bank, and Endogenous Money.” Journal of Post-Keynesian Economics 14.

Wray, Randall. 2013. „How Big is Big Enough: Would the Basic Income Guarantee Satisfy the Unemployed?" Economonitor.

http://www.economonitor.com/lrwray/2013/07/09/how-big-is-big-enough-wouldthe-basic-income-guarantee-satisfy-the-unemployed/ .

Wray, Randall i Eric Tymoigne. 2013. „Modern Money Theory 101: A Reply to Critics.” Levy Economics Institute Working Paper 778: http:/ /www.levyinstitute.org/pubs/wp_778.pdf.

Wray, Randall. 2015. Modern Monetary Theory. London: Palgrave Macmillan. 
Damian Winczewski - absolwent filozofii na Uniwersytecie Gdańskim. Obecnie doktorant filozofii na Uniwersytecie Szczecińskim, gdzie przygotowuje rozprawę poświęconą Róży Luksemburg. Zajmuje się filozofią marksistowską oraz heterodoksyjną ekonomią polityczną.

\section{DANE ADRESOWE:}

Wydział Humanistyczny Uniwersytet Szczeciński

ul. Krakowska 71-79

71-017 Szczecin

EMAIL: damian.winczewski@gmail.com

CYTOWANIE: Winczewski, Damian. 2017. Modern Monetary Theory a marksistowska krytyka ekonomii politycznej. Praktyka Teoretyczna 3 (25): 136-175.

DOI: $10.14746 /$ prt.2017.3.5

\section{AUTHOR: Damian Winczewski}

TITLE: Modern Monetary Theory and Marxist Critique of Political Economy

ABSTRACT: This article is an attempt to discuss the issues represented by Modern Monetary Theory, one of the most popular post-Keynesian theories within the perspective of Marxist political economy. The subject of the analysis will be primarily MMT assumptions about the role of money in the modern world, in juxtaposition with contemporary research analyzing the Marxist theory of commodity money capital. The ideas of neo-chartalists on economic policy in capitalism and its influence on the dynamics of the whole system will also be commented on and evaluated. Another issue is the strictly political problems related to MMT, which will also be analyzed. Common points will be shown, combining some of the MMT concepts with Marxist concepts, while demonstrating the theoretical predominance of Marxist propositions. The author of this article is trying to prove that, while the realism of modern capitalism belongs to the descriptive part, some non-orthodox Marxist economists may accept that the normative part of this theory should be criticized because of its rather superficial repetition of some traditional Keynesian monetary and fiscal policy proposals.

KEYWORDS: Marxism, neo-chartalism, theory of money, political economy. 